NBER WORKING PAPER SERIES

\title{
BUSINESS VOLATILITY, JOB DESTRUCTION, AND UNEMPLOYMENT
}

\author{
Steven J. Davis \\ R. Jason Faberman \\ John Haltiwanger \\ Ron Jarmin \\ Javier Miranda \\ Working Paper 14300 \\ http://www.nber.org/papers/w14300 \\ NATIONAL BUREAU OF ECONOMIC RESEARCH \\ 1050 Massachusetts Avenue \\ Cambridge, MA 02138 \\ September 2008
}

We thank John Abowd, Hoyt Bleakley, Robert Hall and seminar participants at Northwestern University, the University of Chicago, the Stanford Institute for Theoretical Economics and the San Francisco Federal Reserve Bank Conference on Recent Trends in Economic Volatility for helpful comments on earlier drafts. Marios Michaelides provided excellent research assistance. This work is unofficial and has not undergone the review accorded to official Census Bureau publications. The views expressed are those of the authors and do not necessarily reflect the views of the U.S. Bureau of Labor Statistics, the U.S. Bureau of the Census, the Federal Reserve Bank of Philadelphia or their staff members. The views expressed herein are those of the author(s) and do not necessarily reflect the views of the National Bureau of Economic Research.

NBER working papers are circulated for discussion and comment purposes. They have not been peerreviewed or been subject to the review by the NBER Board of Directors that accompanies official NBER publications.

(C) 2008 by Steven J. Davis, R. Jason Faberman, John Haltiwanger, Ron Jarmin, and Javier Miranda. All rights reserved. Short sections of text, not to exceed two paragraphs, may be quoted without explicit permission provided that full credit, including $\left({ }^{\circ}\right.$ notice, is given to the source. 
Business Volatility, Job Destruction and Unemployment

Steven J. Davis, R. Jason Faberman, John Haltiwanger, Ron Jarmin, and Javier Miranda

NBER Working Paper No. 14300

September 2008

JEL No. E24,E32,J60

\begin{abstract}
$\underline{\text { ABSTRACT }}$
Unemployment inflows fell from 4 percent of employment per month in the early 1980s to 2 percent or less by the mid 1990s and thereafter. U.S. data also show a secular decline in the job destruction rate and the volatility of firm-level employment growth rates. We interpret this decline as a decrease in the intensity of idiosyncratic labor demand shocks, a key parameter in search and matching models of unemployment. According to these models, a lower intensity of idiosyncratic shocks produces less job destruction, fewer workers flowing through the unemployment pool and less frictional unemployment. To evaluate the importance of this theoretical mechanism, we relate industry-level unemployment flows from 1977 to 2005 to industry-level indicators for the intensity of idiosyncratic shocks. Unlike previous research, we focus on the lower frequency relationship of job destruction and business volatility to unemployment flows. We find strong evidence that declines in the intensity of idiosyncratic labor demand shocks drove big declines in the incidence and rate of unemployment. This evidence implies that the unemployment rate has become much less sensitive to cyclical movements in the job-finding rate.
\end{abstract}

Steven J. Davis

Graduate School of Business

The University of Chicago

5807 South Woodlawn Avenue

Chicago, IL 60637

and NBER

steve.davis@gsb.uchicago.edu

R. Jason Faberman

Research Department

Federal Reserve Bank of Philadelphia

10 Independence Mall

Philadelphia, PA 19106

Jason.Faberman@phil.frb.org

John Haltiwanger

Department of Economics

University of Maryland

College Park, MD 20742

and NBER

haltiwan@econ.umd.edu

\author{
Ron Jarmin \\ Center for Economic Studies \\ U.S. Census Bureau \\ 4600 Silver Hill Road \\ Washington, DC 20233 \\ ron.s.jarmin@census.gov \\ Javier Miranda \\ Center for Economic Studies \\ U.S. Bureau of the Census \\ 4600 Silver Hill Road \\ Washington, DC 20233 \\ javier.miranda@census.gov
}




\section{Introduction}

Trends in the volatility of economic activity attract considerable attention. Many recent studies examine the "great moderation” in aggregate U.S. fluctuations. ${ }^{1}$ Another recent line of research finds a secular decline in business-level volatility. In this regard, Faberman (2008) documents a decline in the rate at which jobs are reallocated across establishments. Davis, Haltiwanger, Jarmin and Miranda (2006; DHJM) document a decline in the cross-sectional dispersion of business growth rates and in the time-series volatility of business growth rates. ${ }^{2}$ The secular decline in business-level volatility roughly coincides with a marked decline in the magnitude of unemployment flows. Inflows, for example, fell from 4 percent of employment per month in the early 1980s to about 2 percent per month by the mid 1990s.

In this paper, we investigate whether declining business-level volatility and job flows drove the large decline in unemployment flows. The theoretical motivation is a basic one: according to search and matching theories of the labor market, a lower intensity of idiosyncratic labor demand shocks produces less job destruction, fewer workers flowing through the unemployment pool and less frictional unemployment. To evaluate the importance of this theoretical mechanism, we relate industry-level movements in the incidence and duration of unemployment to industry-level movements in several indicators for the intensity of idiosyncratic shocks. Unlike previous research, we focus on the low frequency relationship of job destruction and business volatility to

\footnotetext{
${ }^{1}$ See Kim and Nelson (1999), McConnell and Perez-Quiros (2000), Blanchard and Simon (2001), Stock and Watson (2002), Davis and Kahn (2008) and Gali and Gambetti (2008), among others.

${ }^{2}$ In contrast, Comin and Mulani (2006), and Comin and Philippon (2005) find rising volatility among publicly traded firms in recent decades. It turns out, as DHJM show, that the volatility trend for publicly traded firms differs dramatically from the trend for privately held firms and the private sector as a whole. Privately held firms have become less volatile, and they dominate the overall trend.
} 
unemployment flows. The central question we pursue is whether longer term changes in the intensity of idiosyncratic labor demand shocks explain changes in the extent of (frictional) unemployment, as suggested by canonical search and matching models.

To carry out our empirical investigation, we integrate industry-level data from three sources. We construct annual measures of job creation, job destruction and business-level volatility and dispersion from 1977 to 2001 using the Longitudinal Business Database (LBD) and quarterly measures from 1990 to 2005 using the Business Employment Dynamics (BED). We rely on the Current Population Survey (CPS) for monthly data on unemployment inflows, outflows and escape rates. We average the monthly CPS data to the quarterly and annual frequency with due attention to the withinperiod timing of observations in the LBD and BED.

The industry-level data provide compelling evidence that changes in the intensity of idiosyncratic shocks drove big changes in the incidence of unemployment. This key result holds in the annual and the quarterly data. We estimate, for example, that a decline of 100 basis points in an industry's quarterly job destruction rate lowers its monthly unemployment inflow rate by 28 basis points with a standard error of 6 basis points. This estimate reflects a specification that includes industry and time fixed effects, so it relies entirely on industry-specific time variation. To put the estimate in perspective, the quarterly job destruction rate for the U.S. private sector fell by 174 basis points from 1990 to 2005. Multiplying this drop by its estimated effect yields a decline of 48 basis points in the unemployment inflow rate, which amounts to 55 percent of the drop in the unemployment inflow rate from 1990 to 2005 and 22 percent of its average value. 
We also consider implications for the unemployment rate and its cyclical behavior. Simple approximations and decompositions along the lines of those used by Shimer (2007), Elsby et al. (2008) and Fujita and Ramey (2008) establish three results. First, the steady state unemployment rate fell by 43 log points from 1976-1985 to 19962005. Second, nearly the entirety of this decline reflects a decline in the unemployment inflow rate. This result, when combined with our estimates for the effect of idiosyncratic shock intensity on unemployment inflows, implies that the secular fall in idiosyncratic shock intensity drove about half of the long term decline in the unemployment rate. Third, because of the big decline in unemployment inflows, the unemployment rate is now only about half as sensitive to cyclical movements in the job-finding rate as it was in the 1970s and early 1980s. This observation suggests that cyclical swings in U.S. unemployment rates will remain relatively mild as long as the background levels of business volatility and job destruction remain low.

The next section discusses the theoretical motivation for our empirical investigation and a few conceptual issues. Section 3 describes the data and our measurement procedures. Section 4 presents evidence regarding movements in aggregate volatility, business-level volatility, job destruction rates and unemployment inflows in recent decades. Section 5 carries out our main empirical analysis. Section 6 discusses the implications of our findings for unemployment and its cyclical behavior. Section 7 concludes.

\section{Theoretical Considerations and Conceptual Issues}

The theoretical motivation for our empirical investigation rests on implications of well-known search and matching models. Consider the seminal model of Mortensen and 
Pissarides (1994). When an employer wants to fill a job opening in this model, it posts a vacancy and searches for an unemployed worker. The meeting rate and the aggregate flow of new hires are outcomes of a matching function defined over the stock of vacancies and the number of unemployed persons. Given a standard specification for the matching function, a higher ratio of vacancies to unemployment means a higher jobfinding rate for unemployed persons and a lower job-filling rate for employers. ${ }^{3}$ When employer and job seeker meet, they split the match surplus and commence production. After match formation, employment relationships are subject to aggregate and idiosyncratic shocks that can result in endogenous job destruction. These shocks drive the pace of job destruction and the incidence of unemployment.

The basic MP model assumes an iron link from job destruction to worker separations. Recent empirical analysis of micro data in the Job Openings and Labor Turnover Survey confirms that the link is, in fact, very tight. See Figures 6 and 7 in Davis, Faberman and Haltiwanger (2006) for evidence.

Mortensen and Pissarides show that an increase in the variance of idiosyncratic shocks raises the job destruction rate and the incidence of unemployment in steady state equilibrium. It also raises the vacancy-unemployment ratio in steady state and, hence, raises the job-finding rate. These model properties imply that unemployment inflows and escape rates respond positively to measured job destruction rates and other empirical indicators for the intensity of idiosyncratic shocks. We test these implications in the

\footnotetext{
${ }^{3}$ See Shimer (2007) and Fujita and Ramey (2008) for evidence on the behavior of the job-finding rate and Davis, Faberman and Haltiwanger (2008) for evidence on the job-filling rate.
} 
empirical work below. ${ }^{4}$ See the appendix for a more precise statement of the MP model and these implications.

The idea that idiosyncratic labor demand shocks drive the incidence of unemployment predates its particular expression in Mortensen and Pissarides (1994). It is intrinsic to Friedman's (1968) concept of the natural rate of unemployment. Phelps (1968) provides the first formal model of frictional unemployment, and many, many others follow. Hall (1979) and Pissarides (1985) provide early formalizations that feature idiosyncratic demand shocks as drivers of unemployment inflows and key determinants of the natural rate of unemployment. In light of these remarks, we see our empirical investigation as testing a core idea that inhabits many models of frictional unemployment. We couch our discussion in terms of the MP model because of its central role in recent thinking and research about unemployment. For those already convinced that idiosyncratic demand shocks affect the extent of frictional unemployment, our study quantifies the contribution of longer term changes in the intensity of such shocks to movements in the incidence and rate of unemployment.

In taking the theoretical implications to the data, at least three conceptual issues arise. First, the MP model maintains a sharp distinction between common (“aggregate”) and match-specific ("idiosyncratic”) shocks. In reality, the labor demand effects of common shocks differ greatly among employers. ${ }^{5}$ Indeed, by allowing for heterogeneity in the

\footnotetext{
${ }^{4}$ We do not explore implications of the MP model for vacancy rates, given our focus on low frequency behavior, because U.S. data on job vacancies are not suitable for drawing inferences about trends. In this connection, see Shimer (2005) for a discussion of spurious trends in the normalized Help Wanted Index, the object of many studies that consider the cyclical behavior of job vacancies. Time series on vacancy rates derived from the Job Openings and Labor Turnover Survey are, as yet, too short to draw inferences about trends.

${ }^{5}$ Durable goods producers are more sensitive to aggregate income and wealth shocks according to standard theories of consumption behavior. Persistent technology shocks have a bigger impact effect on the capitalproducing sector in real business cycle models. Exchange rate movements differentially affect importing
} 
impact of common shocks, it is easy to generate a trend decline in firm-level volatility from a decline in the size or frequency of common shocks, as DHJM discuss. Hence, trends in empirical indicators for the intensity of idiosyncratic shocks can reflect changes in the size and frequency of common shocks or changes in firm-level responses to common shocks. We include time fixed effects in our regression specifications to control for the average effect of common shocks in the cross section. The differential effects of common shocks are, for our purposes, the same as idiosyncratic shocks.

Second, the basic MP model allows for only two labor market states, employment and unemployment. In reality, many workers flow in and out of the labor force. If the propensity of job-losing workers to exit the labor force differs among industries or over the course of our sample period, and if such differences are correlated with our indicators for the intensity of idiosyncratic shocks, then we will obtain biased estimates for the effects on unemployment inflows and escape rates. To address this source of potential bias, we rely on industry and time effects as controls in our preferred specifications.

Third, unemployed persons in the MP model are homogeneous, and they have identical job-finding rates at a given point in time. In reality, unemployed persons differ in search intensity, ability to find a suitable match, willingness to accept a job offer and propensity to exit the labor force - all of which lead to heterogeneity in unemployment escape rates. Thus, changes over time in the composition of unemployed workers can affect the unemployment escape rate for reasons outside the MP model. Composition

and exporting firms (e.g., Revenga, 1992). The effect of changes in the corporate income tax rate on a firm's investment incentives depend on the composition of its capital stock (Cummins, Hassett and Hubbard, 1994). The impact of changes in the dividend tax rate depends on the firm's dividend payout rate and its marginal source of investment funds (Auerbach and Hassett, 2005). Kashyap, Stein and Wilcox (1993) and Gertler and Gilchrist (1994) find greater sensitivity to monetary shocks among smaller firms. Davis and Haltiwanger (2001) find that the magnitude of job destruction responses to oil price shocks rises with energy's cost share, capital intensity in production and durability of the output good. Many studies consider regional and industry differences in the response to aggregate shocks (e.g., Clark, 1998). 
effects can arise because the mix of job losers varies over the business cycle, or because the experience, skill mix and other attributes of the population evolve over time. Since we focus on lower frequency relationships in the empirical work, we do not think cyclical changes in the composition of newly unemployed persons are an important concern for our study. ${ }^{6}$ Changes in the composition of the working-age population, which by their nature tend to be persistent, are a bigger concern. They could be correlated with empirical indicators for the intensity of idiosyncratic shocks and independently drive changes in unemployment inflows and escape rates. To deal with this issue, we rely on time effects to control for changes in the overall composition of the working-age population and unemployment pool.

Time effects also deal with changes in the extent of measurement error that otherwise could induce a spurious correlation between unemployment flows and our indicators of idiosyncratic shock intensity. As described below, we construct these indicators from longitudinal employer databases. Reduced measurement error in the employer-level observations or improved longitudinal links could produce a trend decline in the measured intensity of idiosyncratic shocks, even when no such decline is truly present, and a spurious low-frequency correlation with unemployment flows. A similar point applies to changes over time in the methods used to measure unemployment flows. By including time effects as controls to isolate within-industry time variation, we ensure that measurement improvements over time do not drive our results.

\footnotetext{
${ }^{6}$ Cyclical spikes in job destruction rates seldom last more than two quarters in U.S. data, and researchers typically estimate unemployment escape rates in the range of 25 to 40 percent per month. Taken together, these two observations suggest that the impact of job destruction episodes on the composition of the unemployment pool dissipates rather quickly. In addition, Shimer (2007) provides evidence that cyclical movements in the composition of unemployed workers produce only modest changes in the average jobfinding rate of unemployed persons.
} 
In addition to evaluating a key mechanism of the MP model, we investigate whether job destruction has a bigger impact on the incidence of unemployment when the lost jobs reflect exiting businesses, as opposed to those that merely shrink. More generally, we hypothesize that a given amount of job destruction produces greater unemployment inflows when the lost jobs are concentrated at businesses undergoing relatively extreme contractions. This hypothesis is motivated by two previous findings in the empirical literature on labor market flows. First, layoffs are much more likely than quits to result in an unemployment spell. See, for example, Leighton and Mincer (1982) and McLaughlin (1990). Second, Davis, Faberman and Haltiwanger (2006, Figure 7) show that the ratio of layoffs to quits is strongly rising with the contraction rate of employers in the cross section. Combining these two empirical regularities yields the prediction that job destruction produces greater unemployment inflows when the lost jobs are concentrated at businesses undergoing extreme contractions. We test whether this link between unemployment inflows and the concentration of job destruction operates on the timeseries dimension.

\section{Data Sources and Measurement Procedures}

\subsection{Job Flows, Employer Volatility and Cross-Sectional Dispersion}

The Bureau of Labor Statistics (BLS) and the Census Bureau have recently developed longitudinal business data sets that cover the entire private sector of the U.S. economy. The BLS Business Employment Dynamics (BED) program produces quarterly job flow statistics from 1992 based on three-month changes in establishment-level employment. We rely on a version of the BED extended back to 1990 by Faberman (2008). The Census Bureau’s Longitudinal Business Database (LBD) contains firm-level employment 
data in March of each year from 1976 to $2001 .^{7}$ We exploit the LBD to construct annual statistics on job flows, firm volatility and the cross-sectional dispersion of firm growth rates. Our measurement procedures follow Davis, Haltiwanger and Schuh (1996) for job flow statistics and DHJM for firm volatility and dispersion measures.

To carefully define our various indicators for the intensity of idiosyncratic shocks, it is helpful to spell out our measurement mechanics. Define the growth rate from $t-1$ to $t$ at employer $e$ as $g_{e t}=\left(E M P_{e t}-E M P e, t-1\right) / Z_{e t}$, where EMP denotes the number of employees and $Z_{e t}=0.5\left(\mathrm{EMP}_{e t}+\mathrm{EMP}_{e, t-1}\right)$ is a measure of employer size. This growth rate measure has become standard in work on labor market flows because it is symmetric about zero and bounded, affording an integrated treatment of entering, exiting and continuing units. ${ }^{8}$

Using these measures, we can write the rate of job destruction from $t-1$ to $t$ as

$$
J D_{t}=\sum_{e}\left(\frac{Z_{e t}}{Z_{t}}\right)\left|\min \left\{0, g_{e t}\right\}\right|=\sum_{e}\left|\min \left\{0, \mathrm{EMP}_{e t}-\mathrm{EMP}_{e, t-1}\right\}\right| / Z_{t},
$$

where $Z_{t}=\sum Z_{e t}$. Equation (1) says that job destruction from $t-1$ to $t$ is the sum of all employment reductions at shrinking units, and it is expressed as a rate by dividing through by total employment. We can partition the set of shrinking establishments by the severity of contractions to obtain, for example, the rate of job destruction at exits and continuers. The job creation rate $\left(J C_{t}\right)$ can be expressed by substituting the max for the min operator in (1). Job reallocation $\left(J R_{t}\right)$ is defined as the sum of job creation and

\footnotetext{
${ }^{7}$ See Jarmin and Miranda (2002) for details on the LBD and its creation. Jarmin (2006a,b) describes updates and improvements to the LBD over time.

${ }^{8}$ It also has other attractive properties. It is identical to log changes up to a second-order Taylor Series expansion, and the creation and destruction rates calculated according to (1) aggregate consistently. See Tornqvist, Vartia and Vartia (1985) and the appendix to Davis, Haltiwanger and Schuh (1996) for additional discussion.
} 
destruction. Throughout, we multiply job flow rates by 100 and report them as percentages of employment. We do the same for the volatility and dispersion measures described below.

The job reallocation rate is equivalent to the size-weighted mean absolute value of employer growth rates. Thus, it can be interpreted as a measure of cross-sectional dispersion in employer growth rates. We also consider a more conventional measure of cross-sectional dispersion in employer growth rates:

$$
\sigma_{t}(\text { Disp })=\left[\sum_{e}\left(Z_{e t} / Z_{t}\right)\left(g_{e t}-\bar{g}_{t}\right)\right]^{1 / 2},
$$

where $\bar{g}_{t}$ is the size-weighted mean growth rate from $t-1$ to $t$. Equation (2) is the sizeweighted standard deviation of employment growth rates from $t-1$ to $t$ in the cross section of employers. We refer to (2) as the dispersion of employer growth rates.

Several previous studies measure business volatility using a moving window of fixed length, say ten years, on the standard deviation of business-level growth rates. The window is centered on the current year, and the standard deviations are averaged across businesses in each period to obtain a time series for average business volatility. This measure has two major drawbacks for our purposes. First, it is truncated at both ends of the sample period, a loss of valuable information. Second, the measure is undefined for employers that operate during only part of the window. Because most firms do not survive ten years and short-lived firms are highly volatile, a measure based on a fixed window length misses much of the action. Moreover, the omitted units are excluded on the basis of characteristics, entry and exit, associated with highly variable growth paths. 
The nonrandom nature of the selection process raises concerns about the accuracy of the resulting volatility measure as an indicator for the intensity of idiosyncratic shocks.

To address these issues, we follow DHJM by considering a volatility measure that incorporates entry and exit and short-lived business units. The measure is defined over all units at $t$ with a positive value of $Z_{e t}$, as for the measures in (1) and (2). The basic idea of the DHJM measure is to specify a maximal window length but shorten the window length as needed to handle entry and exit and sample end points. To adjust for differences in the window length across units and over time, the measure applies a standard degrees of freedom correction.

Here are the details. Let $P_{e t}$ denote the number of years from $t-4$ to $t+5$ for which $Z_{e t}>0$. Define the scaling quantity, $K_{e t}=P_{e t} / \sum_{\tau=-4}^{5} Z_{e, t+\tau}$, and the rescaled weights, $\tilde{Z}_{e t}=K_{e t} Z_{e t}$. By construction, $\sum_{\tau=-4}^{5} \tilde{Z}_{e t}=P_{e t}$. Our degrees-of-freedom corrected volatility measure for firm $e$ at time $t$ is

$$
\sigma_{e t}(\mathrm{Vol})=\left[\sum_{\tau=-4}^{5}\left(\frac{\tilde{Z}_{e, t+\tau}}{P_{e t}-1}\right)\left(g_{e, t+\tau}-\bar{g}_{e t}\right)^{2}\right]^{1 / 2},
$$

where $\bar{g}_{e t}$ is firm $e$ 's size-weighted mean growth rate from $t-4$ to $t+5$, using the $Z_{e t}$ as weights. We construct this measure for all firms in year $t$ with $Z_{e t}>0$. To obtain the average firm volatility at $t$, we calculate the size-weighted cross-sectional mean of (3):

$$
\sigma_{t}(\mathrm{Vol})=\sum_{e}\left(\frac{Z_{e t}}{Z_{t}}\right) \sigma_{e t}(\mathrm{Vol}) .
$$


Equations (1), (2), (4) and the job reallocation rate are the four main indicators for the intensity of idiosyncratic shocks considered in the empirical investigation below. We construct these measures at aggregate and industry levels. In some of our analysis, we also distinguish between job destruction for continuers and exits. Sampling error is not a concern for these measures, because the BED and LBD are comprehensive universe files with millions of records per year.

\subsection{Unemployment Inflows and Escape Rates}

We estimate monthly series for the unemployment inflow rate and the unemployment escape rate using Current Population Survey data. ${ }^{9}$ Let $U_{i t}^{S}$ denote the number of persons who report an ongoing unemployment spell of less than five weeks and whose most recent work experience is in industry $i . U_{i t}^{S}$ is our estimate for the flow of experienced workers from employment in industry $i$ to the unemployment pool in month $t .{ }^{10}$ To convert this flow to a rate, we divide by the current month’s employment, a departure from the usual practice of dividing by the labor force. We scale by employment because the "labor force" is not well defined at the industry level and because it improves the comparability to our job flow measures.

To estimate the escape rate at time $t$ among unemployed workers from industry $i$,

\footnotetext{
${ }^{9}$ The data are publicly available at http://www.bls.gov/cps/home.htm. We follow Shimer (2005) in adjusting the job finding rate following the 1994 CPS redesign. Shimer (2005) also makes an adjustment to the separation rate for time aggregation bias. As he notes this adjustment is especially relevant for cyclical volatility. Since the job finding rate exhibits little secular movement, this adjustment has little impact on secular changes in our inflow measures.

${ }^{10}$ The unemployment inflow rate for experienced workers excludes new entrants to the labor force. The industry- $i$ inflow rate includes persons who flow into the unemployment pool upon re-entry to the labor force, if they previously worked and their most recent job was in industry $i$. It would be useful to consider an industry-level unemployment inflow measure that captures only persons who transition directly from employment, but the BLS does not regularly produce such a measure.
} 
we calculate $f_{i t}=1-\left(U_{i t}-U_{i t}^{S}\right) / U_{i, t-1}$, where $U_{i t}$ is the total number of unemployed persons in month $t$ whose most recent employment experience is in industry $i$. This escape rate concept involves no requirement that persons return to employment in industry $i$ when they exit unemployment, or even that they return to employment. $f_{i t}$ is simply the exit rate from unemployment for persons who last worked in industry $i$.

\subsection{Integrating the Data Sources}

Two main issues arise in integrating the data across the BED, LBD and CPS. First, to deal with changes and differences in industry classification schemes - especially the wholesale changeover from the SIC to the NAICS and the mapping of the SIC and NAICS systems to the CPS system - we aggregate the data to the following broad industry groups: Mining, Construction, Durable Goods Manufacturing, Nondurable Goods Manufacturing, Transportation \& Utilities, Retail \& Wholesale Trade, FIRE (Finance, Insurance and Real Estate), and Services. ${ }^{11}$ Our main empirical investigation is conducted at this level of aggregation.

The second issue involves the within-period timing of employment observations in the BED and the LBD. Employment observations in the BED are for the payroll period covering the $12^{\text {th }}$ day of the third month in each calendar quarter. For example, the BED-based job destruction rate for the first quarter of 2000 is calculated from establishment-level employment changes from December 1999 to March 2000. We link

\footnotetext{
${ }^{11}$ Even at this level of aggregation, differences between NAICS and SIC require further data integration work. For the LBD-CPS data integration, we use SIC-based industry classifications because both sources are available on an SIC basis for the 1977-2001 period. For the BED-CPS data integration, we use NAICSbased classifications. The BED data are available on a NAICS basis from 1990 to 2005. The CPS data are available on a NAICS basis from 2000 to 2005 and on an SIC basis through 2002. We use the three-year overlap to splice the CPS data and estimate a NAICS-based series from 1990 to 2005.
} 
this job destruction figure to the average value of the monthly unemployment inflow rates in the January, February and March CPS data. Similarly, employment observations in the LBD are for the payroll period covering the $12^{\text {th }}$ day of March. Thus, we link the LBDbased job destruction rate for 2000 to the average value of the monthly unemployment inflow rates in the CPS from April 1999 to March 2000.

Tables 1 and 2 report industry means for the key variables in the integrated BEDCPS and LBD-CPS data sets.

\section{Trends in Volatility, Job Destruction and Unemployment Flows}

\subsection{Aggregate Volatility}

Figures 1 and 2 illustrate the now well-known pattern of declines in the volatility of aggregate U.S. economic activity in recent decades. We measure volatility as the moving ten-period standard deviation of growth rates in real GDP and in private sector employment (measured by the BLS payroll survey). Both output and employment data show large volatility declines, although there are some differences in timing between volatility declines for employment and output in the quarterly data.

\subsection{Business Volatility and Job Flows}

Several recent studies consider volatility at the level of firms and establishments. Comin and Philippon (2005) and Comin and Mulani (2006) argue that firm-level volatility rose over the past several decades despite the fall in aggregate volatility, and they present evidence of declining volatility among publicly traded firms. Davis, 
Haltiwanger, Jarmin, and Miranda (2006) show that when privately held firms are included in the analysis, average business volatility actually fell. ${ }^{12}$

Figure 3 shows two measures of firm-level variability from the DHJM study, $\sigma_{t}\left(\right.$ Disp) and $\sigma_{t}(\mathrm{Vol})$, defined above in equations (2) and (4). The first measure captures movements in the cross-sectional dispersion of employment growth rates, and the second captures movements in the average value of firm-level volatility. Both measures of firm variability drift downward in recent decades, especially since the mid 1980s.

Figure 4 shows trend movements in quarterly job creation and destruction rates, drawing on several data sources. For the manufacturing sector, a clear pattern of declining job creation and destruction dates back to the 1960s. For the U.S. private sector, the available data show a decline in quarterly job creation and destruction rates since the early 1990s. Figure 5 reports annul creation and destruction rates for the private sector from 1977 to 2001, based on the LBD. Consistent with the patterns in Figure 3, the annual rates of job creation and destruction show trend declines over this period, especially since the mid 1980s. Some caution is appropriate in comparing the quarterly patterns in Figure 4 with the annual patterns in Figures 3 and 5 because of differences in frequency, coverage, sample period and measure. However, the broad picture is clear: multiple data sources and various measures of business volatility, business dispersion and job flows point to secular declines in the intensity of idiosyncratic labor demand shocks.

\footnotetext{
${ }^{12}$ DHJM also find a convergence in the volatility of publicly traded and privately held firms. Volatility is low and rising among publicly traded firms, high and falling among privately held firms. DHJM show that much of the volatility convergence reflects an influx of volatile new listings among publicly traded firms and a shift towards older (less volatile) businesses in the privately held group.
} 


\subsection{Unemployment Flows and Escape Rates}

As we have emphasized, our chief objective is to relate longer term changes in indicators for idiosyncratic shock intensity to frictional unemployment. In light of this objective, Figure 6 shows the evolution of unemployment inflow, outflow and escape rates since 1977. Inflow and outflow rates have very similar patterns; both exhibit a pronounced secular decline, with rates falling from 4 percent of employment per month in the early 1980's to about 2 percent by the mid 1990s and later. Escape rates, while strongly cyclical, exhibit little or no secular change.

\section{The Impact of Job Destruction and Business Volatility on Unemployment Flows}

We now examine the relationship of unemployment flows to our empirical indicators for the intensity of idiosyncratic shocks. To begin, we briefly consider how unemployment inflows co-vary with job destruction rates across industries. We then show how unemployment inflows and job destruction evolve over time within industries, highlighting the lower frequency relationship. Next, we fit several regressions designed to estimate the impact of longer term movements in idiosyncratic shock intensity on the unemployment inflow rate. For reasons explained in Section 2, we rely on withinindustry time variation to drive our preferred regression estimates. Lastly, we estimate the effect of idiosyncratic shock intensity on the unemployment escape rate.

\subsection{Job Destruction and Unemployment Inflows across Industries}

Figures 7 and 8 show that unemployment inflow rates are bigger for industries with higher job destruction rates. For example, Figure 7 says that a difference of 100 basis points in the average quarterly job destruction rate corresponds to a difference of 21 
basis points in the average monthly unemployment inflow rate. This result supports the view that industry differences in the intensity of idiosyncratic shocks are a major reason for industry differences in the incidence of unemployment. While Figures 7 and 8 contain few data points, and the between-industry relationship may be affected by confounding factors, the pattern displayed in these figures is quite consistent with the low-frequency comovements over time within industries, as shown below.

\subsection{Job Destruction and Unemployment Inflows over Time within Industries}

Figures 9 and 10 show the joint evolution of job destruction rates and unemployment inflow rates in each major industry. To highlight the lower frequency movements, we show the HP trend for each series along with the raw data. These figures reveal two noteworthy patterns. First, every industry shows a longer term decline in the unemployment inflow rate, although the timing and magnitude of the decline differs among industries. As examples, consider two polar cases in Figure 9. The trend component of monthly unemployment inflows fell by nearly one third (150 basis points) from 1990 to 2000 in Construction, but it dropped only slightly in FIRE. Second, except for Nondurable Manufacturing and FIRE in Figure 10, every industry shows that job destruction rates and unemployment inflow rates move together over the longer term.

\subsection{The Effect of Job Destruction and Other Indicators on Unemployment Incidence}

We now estimate the effect of job destruction and the other indicators for idiosyncratic shock intensity on unemployment inflows. In keeping with our focus on longer term movements, we first compute non-overlapping three-year averages of the industry-level outcomes in each data set. This averaging procedure yields 40 industry- 
level observations from 1990 to 2005 (5 per industry) and 64 industry-level observations from 1977 to 2001 (8 per industry). Using these data, we then regress unemployment inflows on each indicator for idiosyncratic shock intensity. We include industry dummies in all specifications, sweeping out the cross-industry variation highlighted in Figures 7 and 8 . That is, we rely entirely on time variation to estimate the effects on unemployment inflows. We also include time fixed effects in our preferred specifications to isolate within-industry time variation.

Table 3 reports our main results. The top panel considers BED-CPS data from 1990 to 2005, and the bottom panel considers LBD-CPS data from 1977 to 2001. The chief result in Table 3 is the large, statistically significant effects of the indicators for idiosyncratic shock intensity on the unemployment inflow rate. This result holds for both data sets and time periods and regardless of whether we control for time effects.

To appreciate the strength and size of the estimated effects, consider column (4) in the top panel. The data reject the null hypothesis of a zero job destruction effect with a $t$ statistic of about 4.8, despite a sample of only 40 observations and industry and time effects that absorb 13 degrees of freedom. The estimated slope coefficient in column (4) implies that a longer term drop of 100 basis points in the quarterly job destruction rate lowers the monthly unemployment inflow rate by 28 basis points. Applying this estimate to the observed drop in the private sector job destruction rate of 174 basis points from 1990 to 2005 yields a decline in the unemployment inflow rate of 48 basis points. This implied decline in the inflow rate amounts to 55 percent of the observed decline and 22 percent of the average inflow rate from 1990 to 2005. Analogous calculations using the 
quarterly job reallocation rate as the empirical indicator for idiosyncratic shock intensity yield virtually identical results.

The LBD-CPS results in the lower panel of Table 3 also imply powerful effects of job destruction on the incidence of unemployment. The estimated slope coefficient in column (6) says that a drop of 100 basis points in the annual job destruction rate lowers the monthly unemployment inflow rate by 12.6 basis points. Applying this estimate to the job creation drop of 605 basis points from 1983 to 2000 yields a decline in the monthly unemployment inflow rate of 76 basis points. This implied decline amounts to 44 percent of the actual decline in the inflow rate between 1982Q2-1983Q1 and 1999Q22000Q1. ${ }^{13}$ The other annual indicators for idiosyncratic shock intensity have weaker estimated effects on unemployment inflows, and the effect is not statistically significant for the business volatility and dispersion measures.

Figure 11 presents the scatter plot corresponding to column (4) in the top panel of Table 3. That is, we first sweep out industry and time effects, then plot the residual variation in the unemployment inflow rate against the residual variation in the job destruction rate. Similarly, Figure 12 presents the scatter plot corresponding to column (6) in the bottom panel of Table 3. Both scatter plots provide strong visual confirmation that industry-specific movements in the job destruction rate drive large industry-specific responses in the unemployment inflow rate.

Table 3 also considers whether job destruction has a more powerful impact on unemployment inflows when the job-destroying establishment (BED) or firm (LBD) exits completely. The point estimates in Table 3 favor this hypothesis, but the data are not

\footnotetext{
${ }^{13}$ Recall that we measure the annual job destruction rate for, say, 1983, using establishment-level employment changes between March 1982 and March 1983.
} 
sufficiently informative in this regard to draw strong inferences. While there are good reasons to think that a given amount of job destruction yields more unemployment when the lost jobs are concentrated at employers with relatively sharp contractions, as we discussed in Section 2, a definitive assessment of this hypothesis waits on future research.

As robustness checks, we repeated the analysis in Table 3 using non-overlapping five-year time averages of the industry-level outcomes. For the BED-CPS data, the analogue to column (4) of Table 3(a) yields an estimated coefficient of 0.284 (0.061). For the LBD-CPS data, the analogue to column (6) of Table 3(b) yields an estimated coefficient of 0.115 (0.028). These results are nearly identical to the ones reported in Table 3 using three-year averages. We also obtained very similar results in regressions that use the trend components from the Hodrick-Prescott filter. We conclude that the data provide strong support for the view that low frequency movements in job destruction rates have powerful effects on the unemployment inflow rate, and that the secular decline in job destruction rates accounts for much of the longer term decline in the aggregate unemployment inflow rate. The analysis and evidence in Shimer (1998) and Jaimovich and Siu (2008) indicate that the aging of the U.S. labor force after 1980 also accounts for much of the longer term decline in the unemployment inflow rate.

\subsection{Unemployment Escape Rates}

We now estimate the effects of our indicators for idiosyncratic shock intensity on the unemployment escape rate. As before, we first compute non-overlapping three-year averages of industry-level outcomes in each data set. We then fit regressions of the unemployment escape rate on the indicators while controlling for certain fixed effects. 
Table 4 reports the results. Many of the specifications in Table 4 show no statistically significant evidence that the indicators affect the unemployment escape rate. When we control for industry and time effects, the job destruction rate shows a negative and statistically significant relationship to the escape rate, contrary to the steady-state implication of the basic MP model. Column (4) of the top panel implies that a decline in the job destruction rate of 100 basis points raises the escape rate by about 136 basis points. This response is less than 4 percent of the average unemployment escape rate during the 1990 to 2005 sample period. Analogous calculations using the estimated effect of job destruction in column (6) of the bottom panel yields an implied response that amounts to only about 1 percent of the average unemployment escape rate during the 1977 to 2001 period.

In short, we find no support for the hypothesis that a secular decline in idiosyncratic shock intensity lowers the unemployment escape rate. In fact, we find some evidence against the hypothesis. We obtain similar results when we use the job creation rate as the explanatory variable in the escape rate regressions. What might explain our results for the escape rate? One possibility is that time and industry fixed effects do not adequately control for compositional shifts in the unemployment pool that affect the escape rate and that are correlated with the indicators for idiosyncratic shock intensity. A more likely explanation, in our view, involves the ambiguous nature of data on unemployment outflows by industry. Recall that the industry-specific escape rates reflect the industry of most recent employment, not the industry to which the unemployed person "escapes." Our inability to correctly identify the relevant labor market for unemployed persons probably accounts for our weak empirical results with respect to the escape rate. 


\section{Implications for Unemployment}

The results in Section 5 provide evidence that the intensity of idiosyncratic labor demand shocks is a key determinant of unemployment inflows, in line with a basic mechanism in search and matching models. They also show that a secular decline in idiosyncratic shock intensity drove much of the decline in the unemployment inflow rate since the early 1980s and 1990s. To appreciate the implications for the rate of unemployment, consider a simple representation of unemployment dynamics:

$$
u_{t}=l_{t}+\left(1-f_{t}\right) u_{t-1}\left(E_{t-1} / E_{t}\right)
$$

where $u_{t}=U_{t} / E_{t}$ is the ratio of unemployed to employed persons in month $t, l_{t}$ is the unemployment inflow rate in $t$, and $f_{t}$ is the unemployment escape rate. As before, $l_{t}$ and $f_{t}$ are expressed relative to period-t employment and unemployment, respectively.

Shimer (2007) presents evidence that U.S. unemployment rate dynamics are well approximated by the steady state values implied by current-month inflow and escape rates. Imposing $u_{t}=u_{t-1}$ and $E_{t}=E_{t-1}$ in (5) yields the implied steady state unemployment rate, ${ }^{14}$

$$
u_{t}^{S S}=l_{t} / f_{t} \text {. }
$$

Figure 13 confirms that the steady state approximation in (6) closely mimics the actual time path of the unemployment rate. We exploit this result in the remaining analysis.

\footnotetext{
${ }^{14}$ Alternatively, one can consider a stationary path with a constant employment growth rate, which yields $u=l /(f+g)$, where $g$ is the growth rate of employment. At a monthly frequency, however, the employment growth rate is tiny compared to the unemployment escape rate, and this approximation yields results virtually identical to (6). As a separate point, our expression for the steady state unemployment rate differs in appearance from the one in Shimer (2007), because we define the unemployment rate relative to employment (rather than the labor force). See Section 3.2 for an explanation of why we define the unemployment rate this way. At the economy-wide level, the ratio of unemployment to employment behaves similarly to the conventional unemployment rate except for a level shift.
} 
Following Elsby et al. (2008) and Fujita and Ramey (2008), equation (6) yields a useful decomposition for log changes in the unemployment rate:

$$
\Delta \log u_{t}=\Delta \log \left(l_{t}\right)-\Delta \log \left(f_{t}\right)
$$

Using the average steady state unemployment rate from the first ten years (1976-85) and last ten years (1996-2005) of our sample period, we find that $\Delta \log u_{t}=-0.43$ with $\Delta \log l_{t}=-0.41$ and $\Delta \log f_{t}=0.02$. That is, the long term decline of 43 log points in the (steady state) unemployment rate is overwhelmingly accounted for by the decline in the inflow rate.

Recall from Table 3 that declines in the intensity of idiosyncratic shocks explain about half of the longer term decline in unemployment inflow rates, somewhat more for the period since the early 1990s and somewhat less for the period since the early 1980s. Thus, the Table 3 results combined with the decomposition (7) imply that secular declines in the intensity of idiosyncratic shocks account for about half of the long term declines in U.S. unemployment rates. This is a very large effect, especially for a parameter often treated as an unchanging constant in quantitative theoretical analyses of unemployment dynamics. $^{15}$

To further develop this point, we again rely on the steady state approximation (6), this time to compare the unemployment series implied by the 1976-1980 and 2001-2005 average unemployment inflow rates to each other and to the series implied by the contemporaneous inflow rate. In each case, we consider the actual time path of unemployment escape rates in calculating (6).

\footnotetext{
${ }^{15}$ Elsby et al. (2008) and Fujita and Ramey (2008) provide citations to research on unemployment dynamics that treats the job destruction rate or the worker separation rate as time invariant.
} 
The resulting series, plotted in Figure 14, highlight two related points. First, the drop in the inflow rate between the first and last 5 years of the sample implies a large drop in the unemployment rate for all realized values of the escape rate. The average difference between the unemployment rate based on the average 1976-80 and 2001-05 inflow rates is 2.2 percentage points, and the minimum difference is 1.8 percentage points. Second, the escape rate cannot account, by itself, for most of the decline in the unemployment rate since the early 1980s. The steady state unemployment rate fell from 12.6 percent in the fourth quarter of 1982 to 5.1 percent in the fourth quarter of 2005, a decline of 7.5 percentage points. Over the same time period, the unemployment rate implied by the average 1976-80 (2001-05) inflow rate fell by only 2.4 (1.7) percentage points. That is, holding the inflow rate fixed, the escape rate accounts for less than a third of the fall in the unemployment rate from 1982 to 2005.

Our point here is not to deny the importance of movements in the escape rate (or job-finding rate) for unemployment dynamics. Rather, we think our analysis and evidence show that a satisfactory theory of unemployment rate dynamics involves major roles for movements in both unemployment inflow and escape rates. In this respect, our message is similar to that of Elsby et al. (2008) and Fujita and Ramey (2008). Our analysis differs from theirs in its focus on longer term movements in the unemployment inflow rate and in developing evidence that declines in the intensity of idiosyncratic shocks drove much of the secular decline in the inflow rate.

In closing this section, we remark that the secular decline in the inflow rate also has important implications for the cyclical behavior of the unemployment rate. To see 
this point, differentiate (6) to calculate the marginal effect of the job-finding rate on the unemployment rate:

$$
d u / d f=-l /\left(f^{2}\right)
$$

That is, a secular decline in the job-loss rate lowers the unemployment rate response to cyclical movements in the job-finding rate. How big is this effect? Let $f=.41$ and suppose that $l$ falls from 0.04 to 0.02 percent, roughly equivalent to what we observe in the data over our sample period. Then, the marginal effect of the job-finding rate falls in magnitude from -0.24 to -0.12 . This is an enormous drop, and it helps explain why the weak labor markets in the early 1990s and early 2000s involved modest unemployment spikes compared to recessions in the 1970s and 1980s.

This calculation also underscores a related point: Even when the focus is on cyclical unemployment fluctuations and one takes the view that cyclical movements in the jobloss rate are unimportant (e.g., Hall, 2005), the secular decline in the job-loss rate remains important because it affects the unemployment response to the job-finding rate. By the same logic, the secular decline in the intensity of idiosyncratic labor demand shocks is an important development for modeling and understanding cyclical movements in the unemployment rate.

\section{Concluding Remarks}

We find compelling evidence that the intensity of idiosyncratic labor demand shocks is a key factor determining the incidence of unemployment. Indicators for the intensity of idiosyncratic shocks are positively related to unemployment inflow rates across major industry groups, over time at the aggregate level, and over time within industries. This empirical relationship holds for several indicators, but the estimated effects are strongest 
and most consistent across time periods and data sources when we use the job destruction rate as an indicator for the intensity of idiosyncratic shocks.

Our preferred estimate for the effects of idiosyncratic shock intensity exploits industry-specific movements in job destruction and unemployment inflow rates. The industry-level data allow us to control for time effects and to rely on lower frequency variation to estimate the relationship. Using this type of variation, we estimate that declines in the intensity of idiosyncratic shocks account for about one half of the large secular declines in the unemployment inflow rates since the early 1980s and 1990s. Putting this estimate together with a simple accounting decomposition for unemployment dynamics, we conclude that declines in the intensity of idiosyncratic shocks explain about half the long term decline in the unemployment rate in recent decades.

We interpret these results as strongly confirming the importance of a key mechanism in leading search and matching models - namely the link from idiosyncratic shocks to job destruction to unemployment inflows. Our results and analysis also suggest that the development of these models could usefully devote greater attention to changes in the intensity of idiosyncratic shocks as a driving force in the longer term evolution and an important determinant of cyclical volatility in unemployment rates. With respect to future empirical work, an important question is whether the strong relationships documented in this paper for the United States hold in other countries as well. 


\section{Appendix: The Mortensen-Pissarides Model and its Steady State Properties}

The model is set in continuous time, and workers and firms discount the future at rate $r$. Workers are fixed in number, and each one is either employed and producing or unemployed and searching for a job. There is no on-the-job search. When employed, a worker receives wages that provide a fixed share $\beta$ of surplus in the job-worker match. When unemployed, a worker receives income (or imputed leisure value) $b$ per unit time.

Each firm has one job that can be either filled and producing or unfilled and searching for a worker. An unfilled job (vacancy) incurs recruiting costs $c$ per unit time. There are no other costs of creating or destroying jobs. The number of firms adjusts endogenously to satisfy a free-entry condition that ensures zero equilibrium asset value for unfilled jobs.

A filled job produces an output flow valued at $p+\sigma \varepsilon$, where $p$ is a common component of productivity, $\varepsilon$ is an idiosyncratic shock value, and $\sigma$ indexes the average magnitude of idiosyncratic shocks. The value of output in new jobs (i.e., newly filled by a worker) is $p+\sigma \varepsilon_{u}$, the upper support of the productivity distribution. Once a job is filled, productivity evolves exogenously according to Poisson arrival processes for common and idiosyncratic shocks. An idiosyncratic shock brings a new value of $\varepsilon$ drawn from distribution $F(x)$ with finite upper support $\varepsilon_{u}$ and no mass points. $F(x)$ has zero mean and unit variance so that $\sigma$ is the standard deviation of the job-specific productivity component $\sigma \varepsilon$.

Because it is costly and time consuming to find a new worker, a filled job is destroyed only when the idiosyncratic component falls below $\varepsilon_{d}<\varepsilon_{u}$, where the job 
destruction threshold $\varepsilon_{d}$ is an endogenous variable that depends on parameters of the model. The job destruction rate is $\lambda F\left(\varepsilon_{d}\right)$.

Unfilled jobs and unemployed workers meet according to a matching function $m(v, u)$, where $v$ and $u$ are the number of vacancies and unemployed workers, respectively, normalized by the fixed labor force. The matching function is homogeneous of degree one in $v$ and $u$, so we can write the job-finding rate for unemployed workers (i.e, the unemployment escape rate) as $m(v / u, 1)$.

We interpret $\sigma$ as the parameter that governs the intensity of idiosyncratic shocks in the MP model. In their appendix, Mortensen and Pissarides (1994) show that $p>b$ is sufficient to obtain $\mathrm{d} \varepsilon_{d} / \mathrm{d} \sigma>0$ in steady state equilibrium. That is, a lower value of $\sigma$ leads to a lower job destruction rate and a lower unemployment inflow rate. Under a stronger requirement that MP regard as reasonable and impose in their analysis, they also show that $\left.\frac{\partial \varepsilon_{d}}{\partial \sigma}\right|_{v / u \text { fixed }}>0 .{ }^{16}$ That is, a lower value of $\sigma$ leads to a lower job destruction rate and a lower unemployment inflow rate for given labor market tightness. This result also implies that a lower value of $\sigma$ leads to a lower rate of unemployment in light of the steady state condition for unemployment inflows and outflows:

$$
u=\frac{\lambda F(x)}{\lambda F(x)+m(v / u, 1)}
$$

Finally, Mortensen and Pissarides also show that a lower value of value of $\sigma$ yields a lower steady state unemployment escape rate.

\footnotetext{
${ }^{16}$ See page 402 and the discussion of equation (11) in Mortensen and Pissarides (1994).
} 
Alternatively, one might be inclined to associate $\lambda$ with the intensity of idiosyncratic shocks, because a higher value of $\lambda$ means more frequent arrival of such shocks. However, the steady state job destruction rate falls when $\lambda$ rises in the MP model. In part, this property of the model arises because the job-specific component of match output is less persistent at a higher value of $\lambda$, which increases the option value of a filled job for given values of $\varepsilon$ and $v / u$. 


\section{References}

Auerbach, Alan J. and Kevin A. Hassett, 2007, "The 2003 Dividend Tax Cuts and the Value of the Firm: An Event Study,” in Auerbach, James Hines and Joel Slemrod, editors, Taxing Corporate Income in the $21^{\text {st }}$ Century, 93-126.

Blanchard, Oliver J. and Peter Diamond, 1990, "The Cyclical Behavior of Gross Flows of U.S. Workers,” Brookings Papers on Economic Activity, 1990:2, 85-143.

Blanchard, Oliver J., and John Simon, 2001, “The Long and Large Decline in U.S. Output Volatility,” Brookings Papers on Economic Activity, Vol. 1, 2001, 135-164.

Clark, Todd E., 1998, "Employment Fluctuations in U.S. Regions and Industries: The Roles of National, Region-Specific, and Industry-Specific Shocks,” Journal of Labor Economics, 16, no. 1 (January), 202-229.

Comin, Diego and Sunil Mulani, 2006, "Diverging Trends in Aggregate and Firm Volatility,” Review of Economics and Statistics, 88(2), 374-383.

Comin, Diego, and Philippon, Thomas, 2005, “The Rise in Firm-Level Volatility: Causes and Consequences” in Mark Gertler and Kenneth Rogoff, eds., NBER Macroeconomics Annual 2005. Cambridge, MA: MIT Press, pp. 167-201.

Cummins, Jason G., Kevin A. Hassett and R. Glenn Hubbard, 1994, “A Reconsideration of Investment Behavior Using Tax Reforms as Natural Experiments,” Brookings Papers on Economic Activity, no. 2, 1-74.

Davis, Steven J., R. Jason Faberman and John Haltiwanger, 2006, “The Flow Approach to Labor Markets: New Evidence and Micro-Macro Links,” Journal of Economic Perspectives, 20(3): 3-24.

Davis, Steven J., R. Jason Faberman, and John Haltiwanger, 2008, “The EstablishmentLevel Behavior of Vacancies and Hiring,” working Paper, University of Chicago.

Davis, Steven J. and John Haltiwanger, 2001, "Sectoral Job Creation and Destruction Responses to Oil Price Changes," Journal of Monetary Economics, 48(3) (December), 465-512.

Davis, Steven J., John Haltiwanger, Ron Jarmin, and Javier Miranda, 2006, "Volatility and Dispersion in Business Growth Rates: Publicly Traded versus Privately Held Firms," in Daron Acemoglu, Kenneth Rogoff, and Michael Woodford, eds., NBER Macroeconomics Annual 2006.

Davis, Steven J., John C. Haltiwanger, and Scott Schuh, 1996, Job Creation and Destruction. Cambridge, MA: MIT Press. 
Davis, Steven J. and James A. Kahn, 2008, "Interpreting the Great Moderation: Changes in the Volatility of Economic Activity at the Macro and Micro Levels,” Journal of Economic Perspectives, 22(3).

Elsby, Michael, Ryan Michaels, and Gary Solon, 2008, “The Ins and Outs of Unemployment,” forthcoming, American Journal of Economics: Macroeconomics.

Faberman, R. Jason, 2008, “Job Flows, Jobless Recoveries, and the Great Moderation,” Federal Reserve Bank of Philadelphia Working Paper No. 08-11.

Friedman, Milton, 1968, “The Role of Monetary Policy,” American Economic Review, 58(1) (March), 1-17.

Fujita, Shigeru and Garey Ramey, 2008, “The Cyclicality of Separation and Job Finding Rates,” forthcoming, International Economic Review.

Gali, Jordi and Luca Gambetti, 2008, “On the Sources of the Great Moderation,” forthcoming, American Economic Journal: Macroeconomics.

Gertler, Mark and Simon Gilchrist, 1994, "Monetary Policy, Business Cycles and the Behavior of Small Manufacturing Firms,” Quarterly Journal of Economics, 109, 309340.

Hall, Robert E., 1979, “A Theory of the Natural Unemployment Rate and the Duration of Employment,” Journal of Monetary Economics, 5, 153-169.

Hall, Robert E., 2005, “Job Loss, Job Finding, and Unemployment in the U.S. Economy over the Past Fifty Years,” NBER Macroeconomics Annual 2005, 101-137.

Jaimovich, Nir and Henry E. Siu, 2008, “The Young, the Old, and the Restless:

Demographics and Business Cycle Volatility,” forthcoming, American Economic Review.

Jarmin, Ron S., and Javier Miranda, 2002, “The Longitudinal Business Database,” CES Working Paper 02-17.

Kashyap, Anil K., Owen A. Lamont and Jeremy C. Stein, 1993, "Monetary Policy and Credit conditions: Evidence from the Composition of External Finance,” American Economic Review, 83, 78-98.

Kim, Chiang-Jin, and Charles R. Nelson, 1999, "Has the U.S. Economy Become More Stable? A Bayesian Approach Based on a Markov-Switching Model of the Business Cycle,” Review of Economics and Statistics, 81(4), 608-616.

Leighton, Linda and Jacob Mincer, 1982, "Labor Turnover and Youth Unemployment," in The Youth Labor Market Problem: Its Nature, Causes and Consequences, edited by Richard Freeman and David Wise. Chicago: University of Chicago Press. 
McConnell, Margaret M., and Gabriel Perez-Quiros, 2000, "Output Fluctuations in the United States: What has Changed Since the Early 1980's?” American Economic Review, 90(5) (December), 1464-1476.

McLaughlin, Kenneth J., 1990, "General Productivity Growth in a Theory of Quits and Layoffs,” Journal of Labor Economics, 8, no. 1 (January), 75-98.

Miranda, Javier, 2006(a), “LBD Documentation: Procedures to Update the LBD,” CES Technical Notes CES-TN-2006007, Center for Economic Studies, U.S. Census Bureau.

Miranda, Javier, 2006(b), "LBD Documentation: Splitters and Combined Reports in the SSEL,” CES Technical Note CES-TN-2006-10, Center for Economic Studies, U.S.

Census Bureau.

Mortensen, Dale T., and Christopher A. Pissarides, 1994, "Job Creation and Job Destruction in the Theory of Unemployment," Review of Economic Studies 61(3) (July): 397-415.

Phelps, Edmund S., 1968, “Money-Wage Dynamics and Labor-Market Equilibrium,” Journal of Political Economy, 76, 678-711.

Pissarides, Christopher, 1985, “Short-Run Equilibrium Dynamics of Unemployment, Vacancies, and Real Wages,” American Economic Review, 75, no. 4 (September), 676690.

Revenga, Ana L., 1992, "Exporting Jobs?: The Impact of Import Competition on Employment and Wages in U.S. Manufacturing," Quarterly Journal of Economics, 107, no. 1 (February), 255-284.

Shimer, Robert, 1998, "Why Is the U.S. Unemployment Rate So Much Lower?” NBER Macroeconomics Annual, 13, edited by Ben Bernanke and Julio Rotemberg. MIT Press: Cambridge, Massachusetts.

Shimer, Robert, 2005, “The Cyclical Behavior of Unemployment and Vacancies,” American Economic Review, 95, 24-49.

Shimer, Robert, 2007, "Reassessing the Ins and Outs of Unemployment,” working paper, University of Chicago.

Stock, James H., and Mark W. Watson, 2002, "Has the Business Cycle Changed and Why?” in Mark Gertler and Kenneth Rogoff, eds., NBER Macroeconomics Annual 2002. Cambridge, MA: MIT Press, pp. 159-218.

Tornqvist, Leo, Pentti Vartia, and Yrjo Vartia, 1985, "How Should Relative Change Be Measured?” American Statistician, 39(1), 43-46. 
Figure 1. Volatility of Real GDP and Employment Growth Rates, Quarterly Data

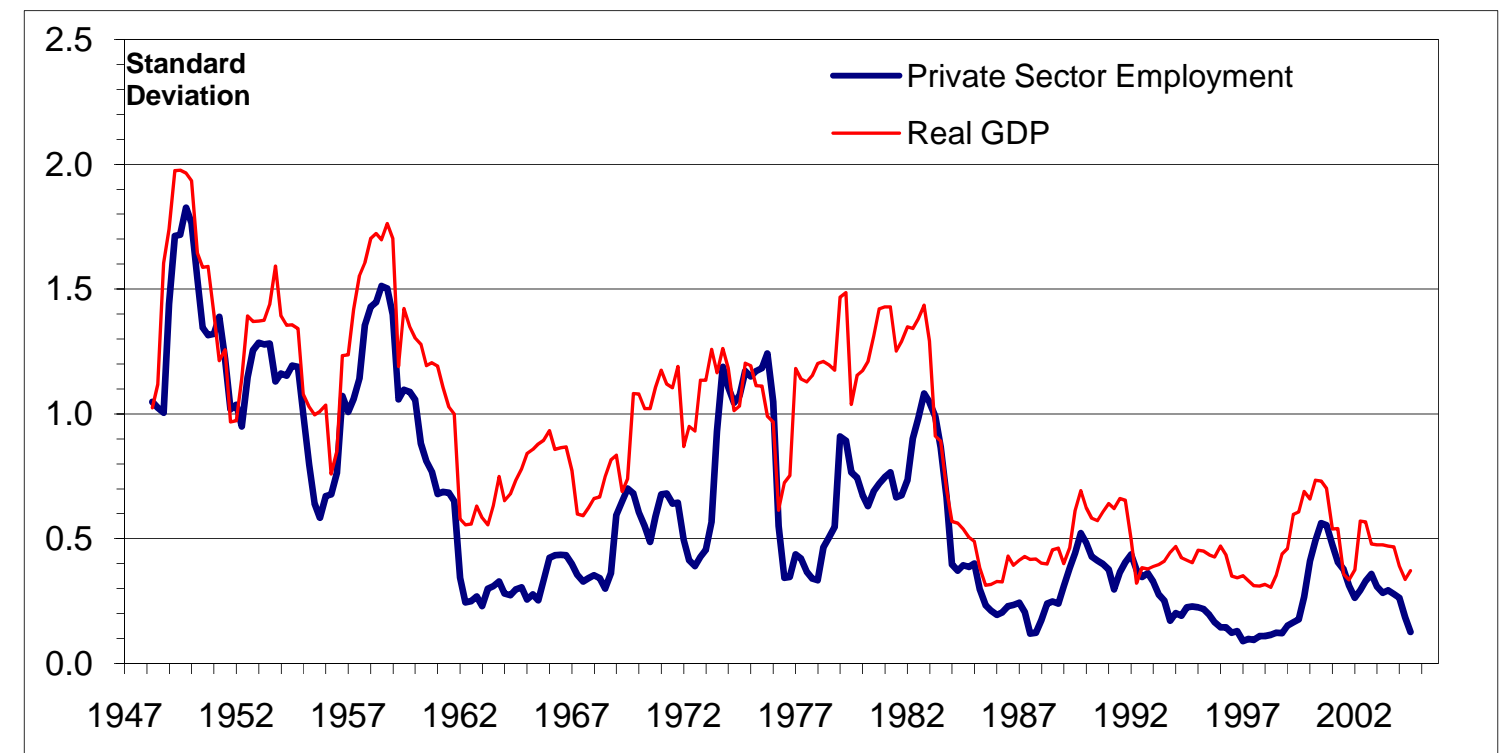

Notes: Volatility at $t$ measured as the standard deviation of growth rates from $t-4$ to $t+5$, using aggregate data. Employment data are from the BLS payroll survey.

Figure 2. Volatility of Real GDP and Employment Growth Rates, Annual Data

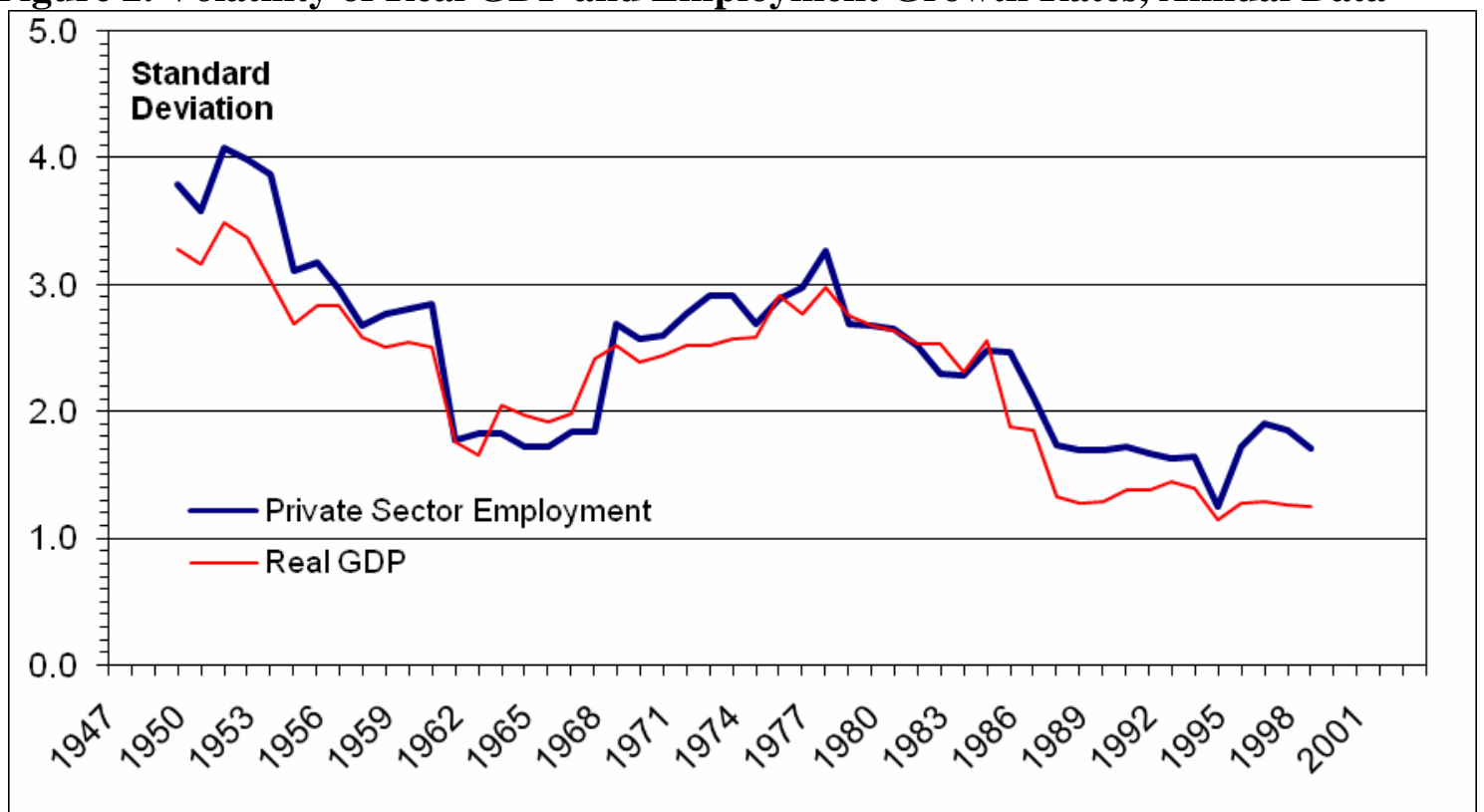

Notes: Volatility at $t$ measured as the standard deviation of growth rates from $t-4$ to $t+5$, using aggregate data. Employment data are from the BLS payroll survey. 
Figure 3. Dispersion and Volatility in Firm-level Employment Growth Rates

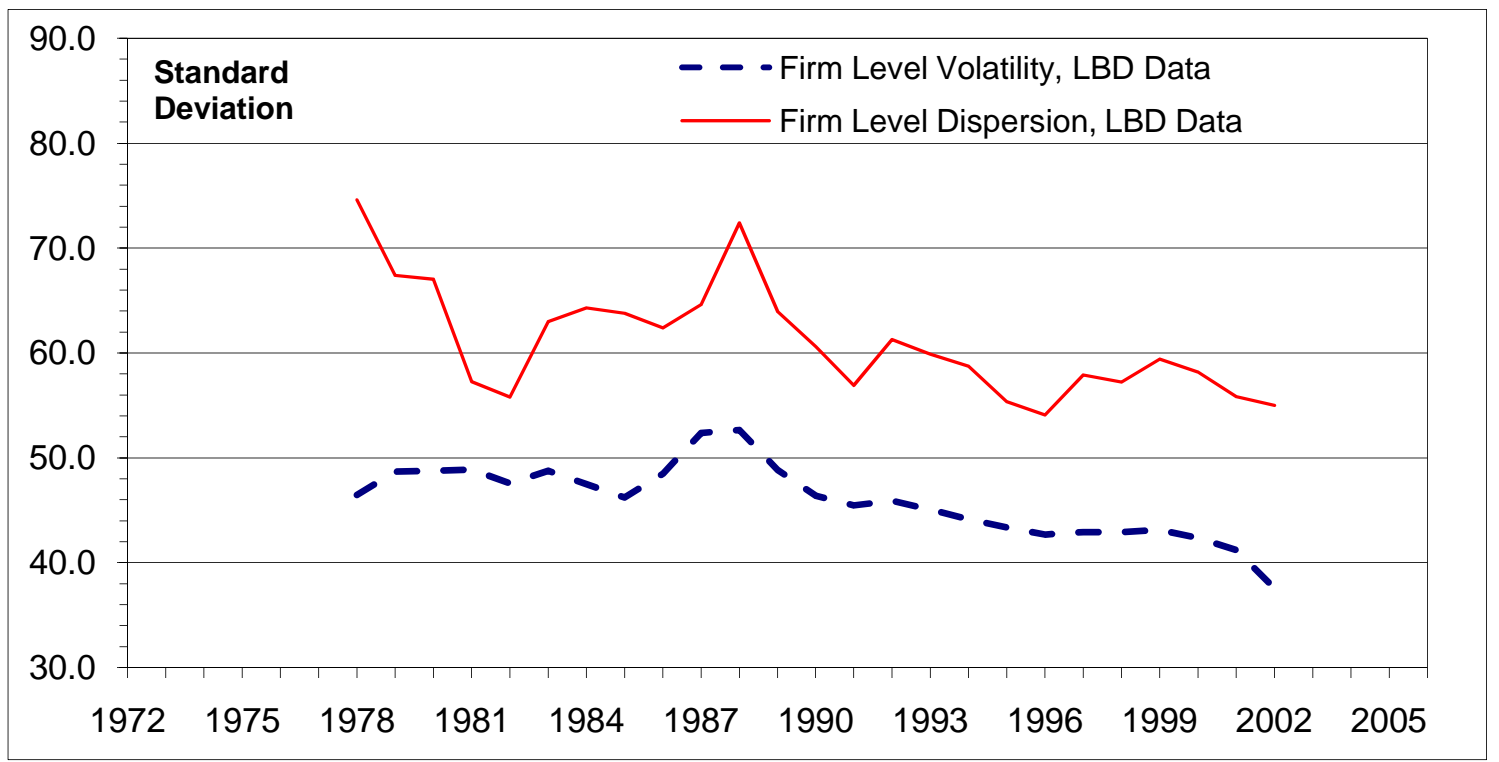

Notes: Dispersion and volatility measures from Davis, Haltiwanger, Jarmin, and Miranda (2006). We construct these measures per equations (2) and (4) in the text using firm-level data from the Longitudinal Business Database. 
Figure 4. Quarterly Job Flows Trends, Manufacturing and Nonfarm Business

(a) U.S. Manufacturing, 1947-2005

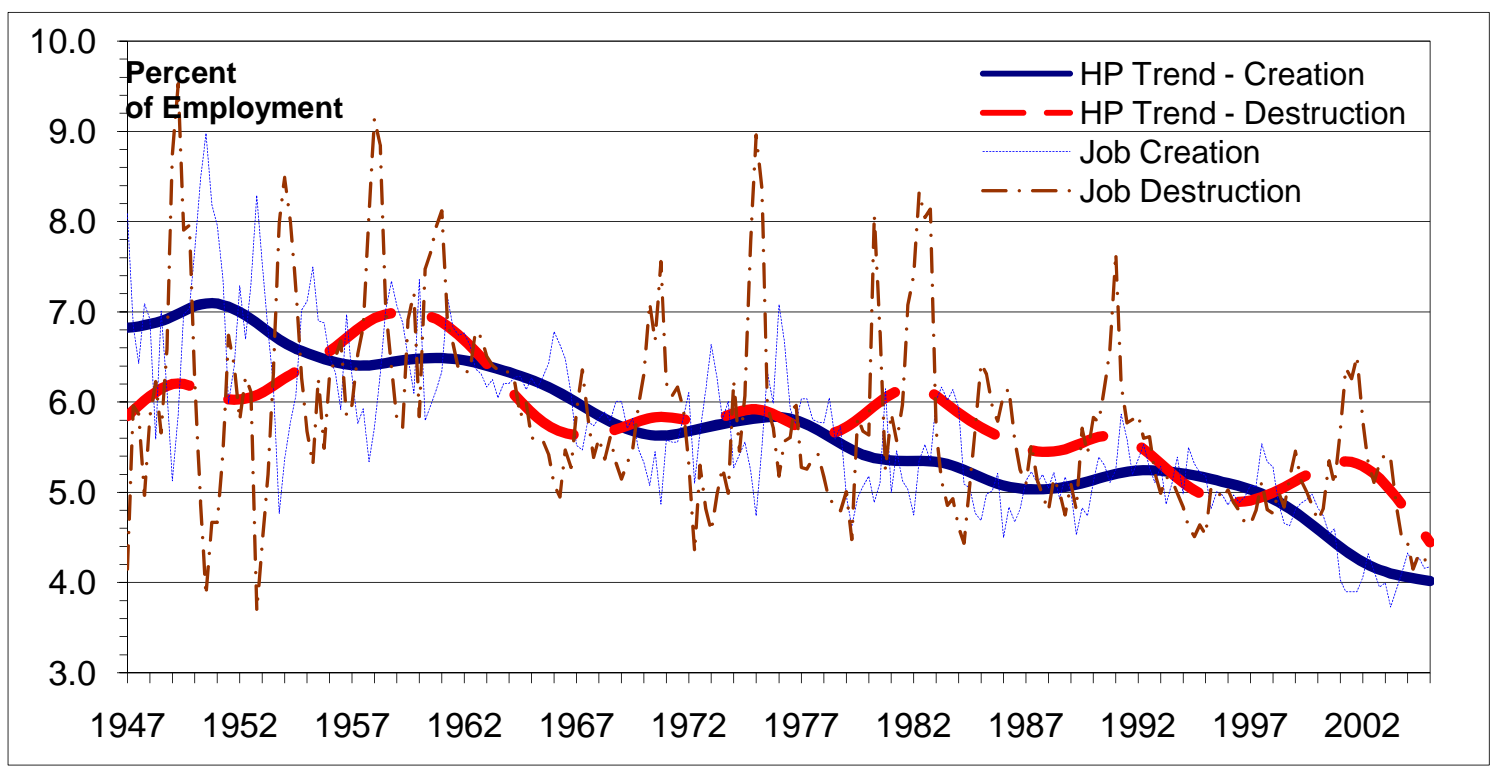

(b) Nonfarm Private, 1990 Q 2 to $2005 Q 1$

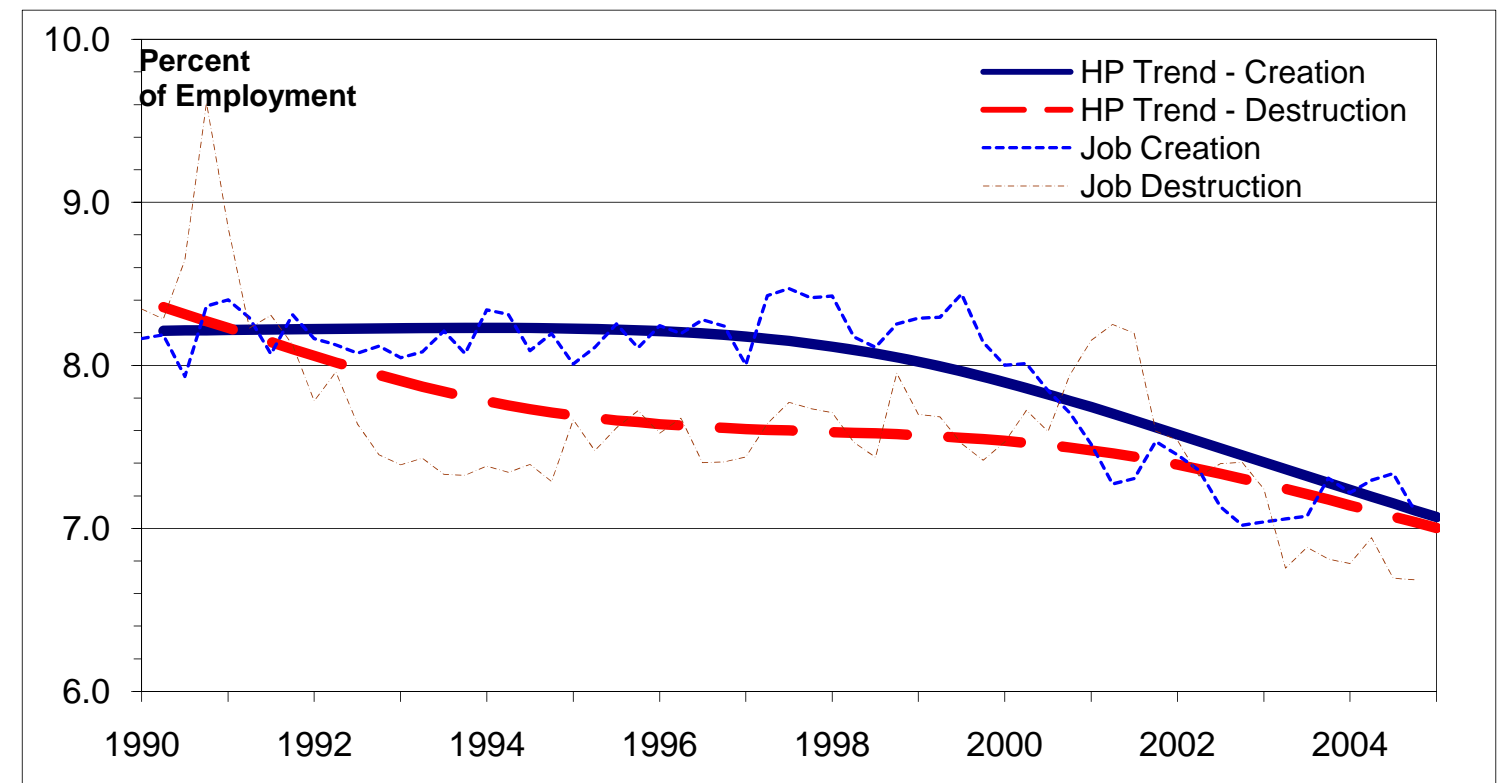

Notes: The figures show quarterly job creation and destruction rates (percent of employment) and HodrickPrescott trends with smoothing parameter $\lambda=1600$. To construct the upper panel, we splice data on manufacturing job flow rates from multiple data sources. To construct the lower panel, we use micro data from Business Employment Dynamics. See Faberman (2008) and Davis, Faberman, and Haltiwanger (2006) for details. 
Figure 5. Annual Job Flow Trends, U.S. Nonfarm Business Sector, 1977-2001

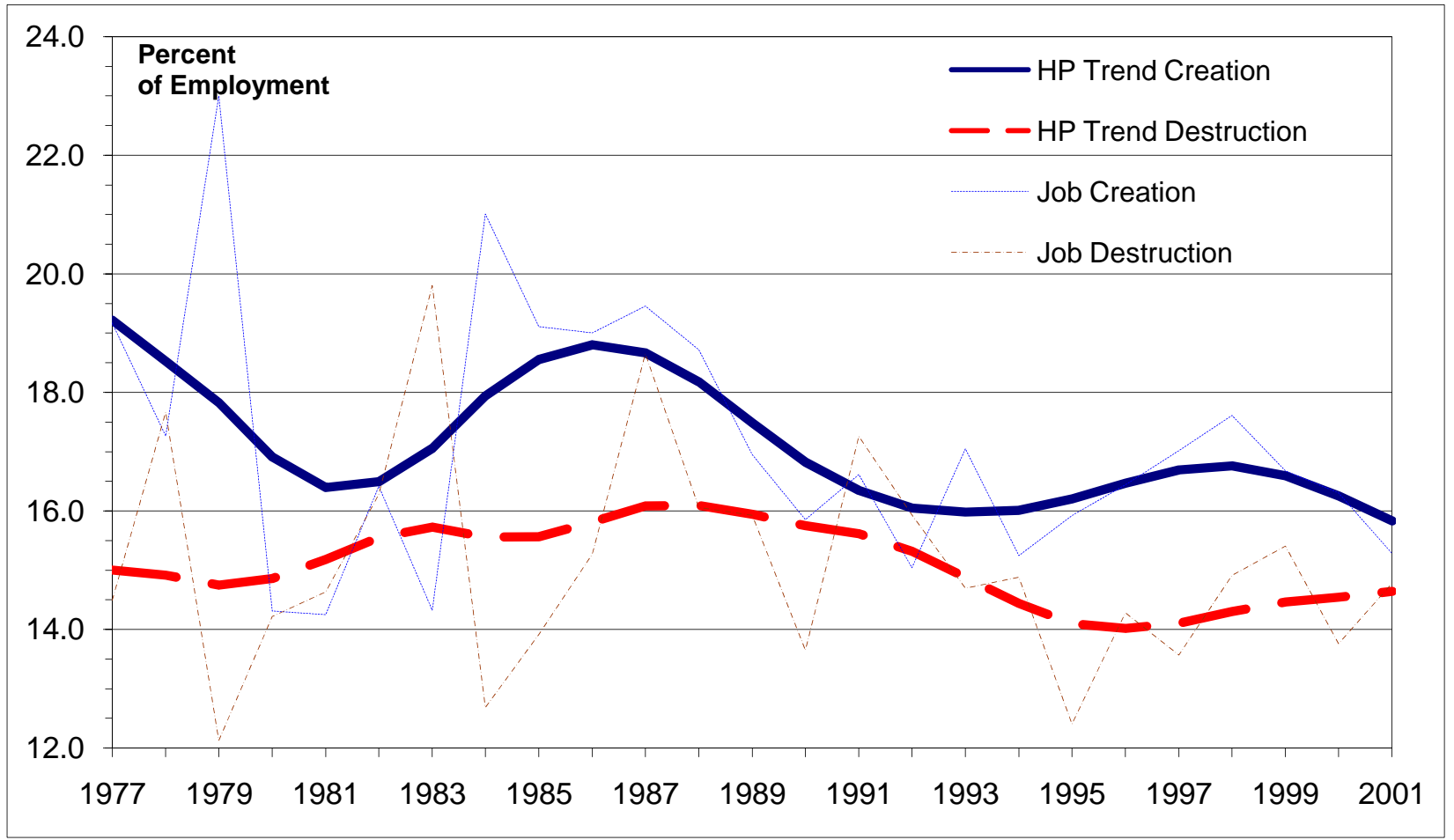

Notes: The figure shows annual job creation and destruction rates (percent of employment) and HodrickPrescott trends with a smoothing parameter of $\lambda=6.25$. We construct the job flow rates using firm-level data from the Longitudinal Business Database. 
Figure 6. Monthly Unemployment Inflow, Outflow and Escape Rates, Quarterly Averages

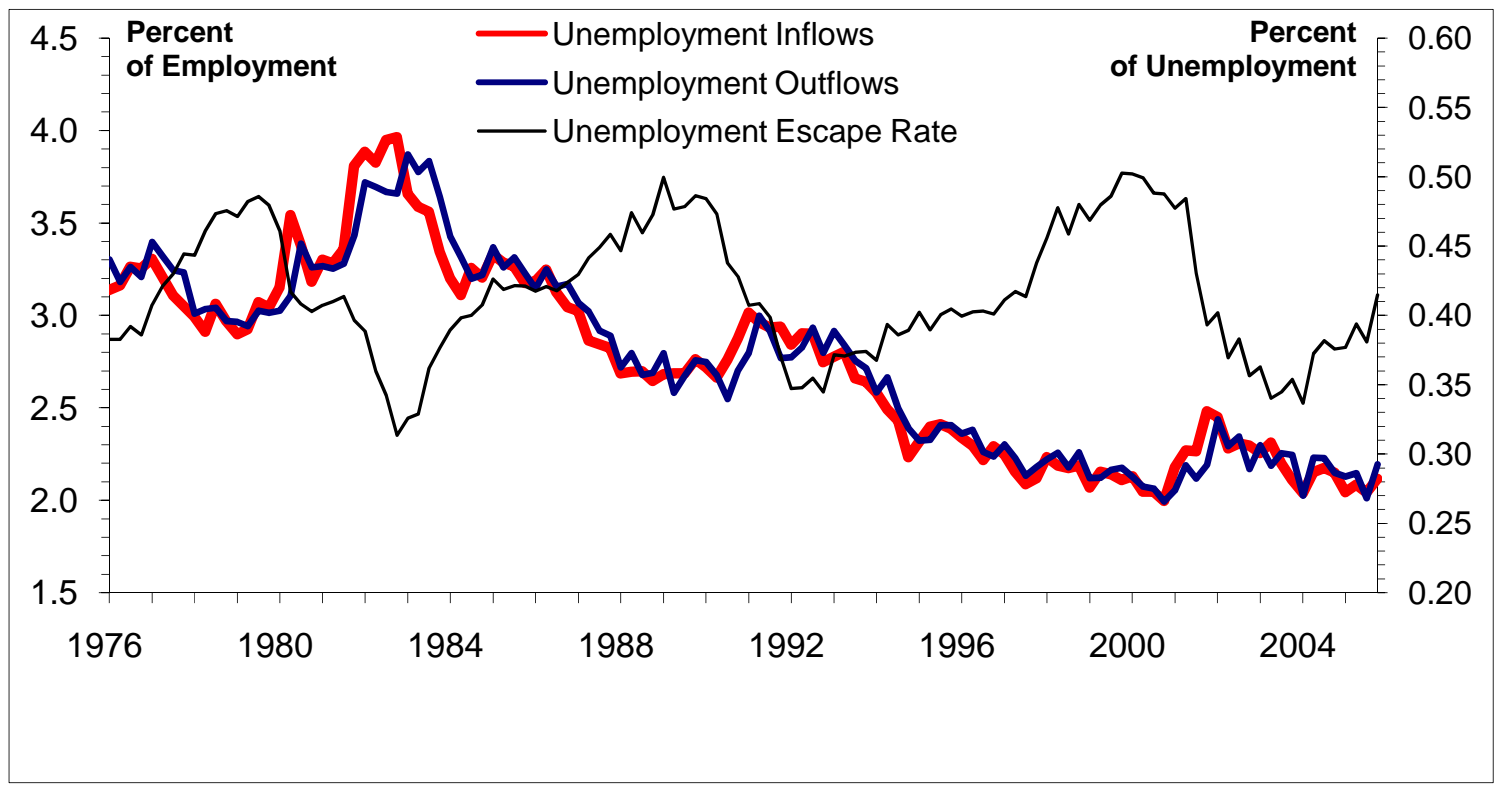

Notes: The figure shows monthly unemployment inflow and outflow rates (left axis) and the monthly escape rate out of unemployment (right axis). All rates are quarterly averages of seasonally adjusted monthly rates constructed from the Current Population Survey. 
Figure 7. Job Destruction and Unemployment Inflows by Major Industry Group, 1990-2005 Averages of Quarterly Data

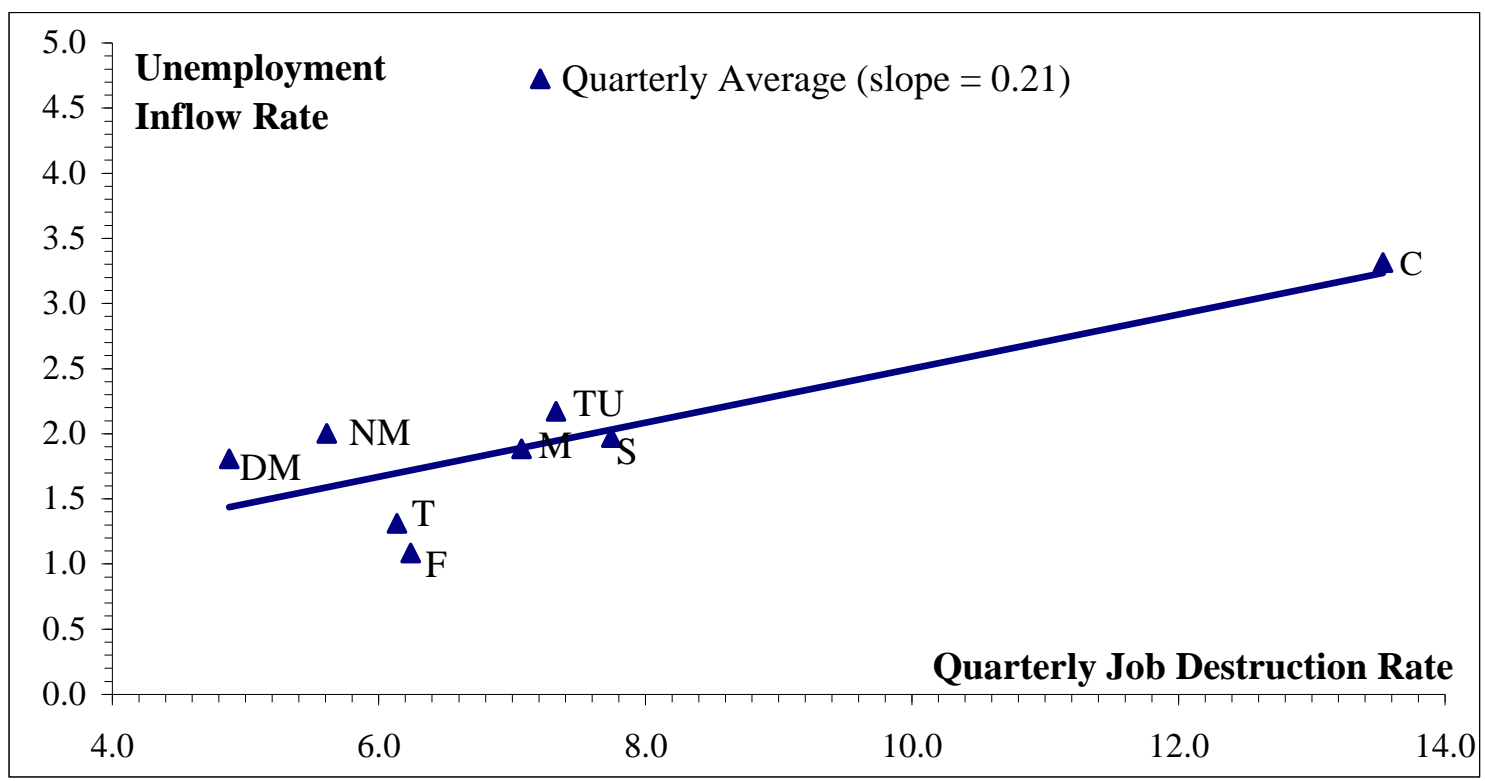

Note: Unemployment inflow rates from the Current Population Survey and job destruction rates from the Business Employment Dynamics, averaged over 1990Q2 -2005Q1 and plotted for 8 major industry groups: Mining (M), Construction (C), Durable Manufacturing (DM), Nondurable Manufacturing (NM), Transportation \& Utilities (TU), Trade (T), FIRE (F), and Services (S). The solid line is the fitted OLS relation of the time-averaged observations. 
Figure 8. Job Destruction and Unemployment Inflows by Major Industry Group, 1977-2001 Averages of Annual Data

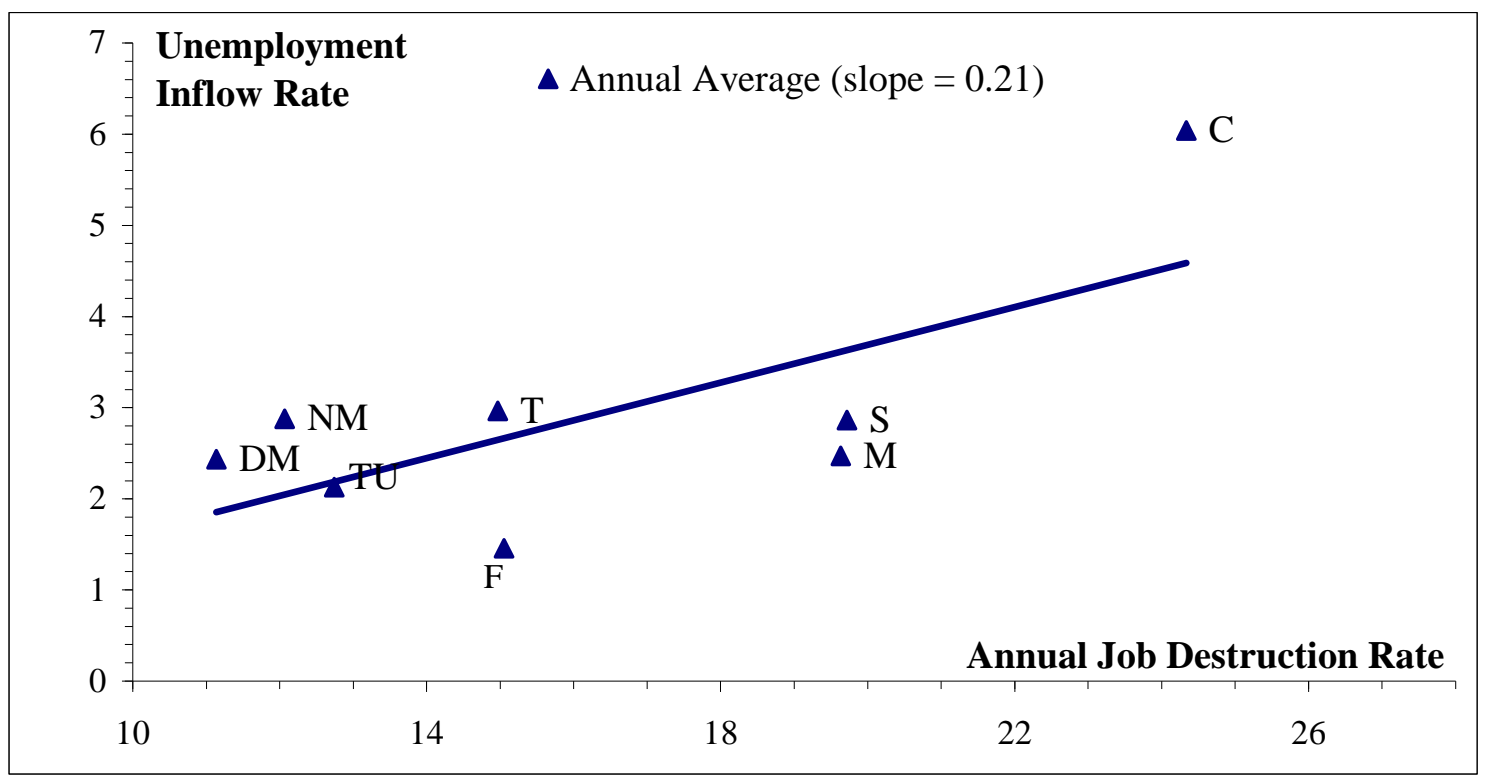

Note: Unemployment inflow rates from the Current Population Survey and job destruction rates from the Longitudinal Business Database, averaged over 1977-2001 and plotted for 8 major industry groups: Mining (M), Construction (C), Durable Manufacturing (DM), Nondurable Manufacturing (NM), Transportation \& Utilities (TU), Trade (T), FIRE (F), and Services (S). The solid line is the fitted OLS relation of the time-averaged observations. 
Figure 9. Job Destruction and Unemployment Inflow Rates by Industry, Quarterly

Mining

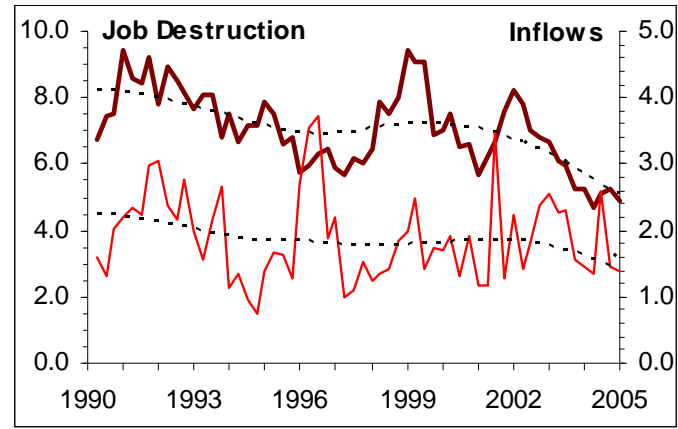

Durable Goods Manufacturing

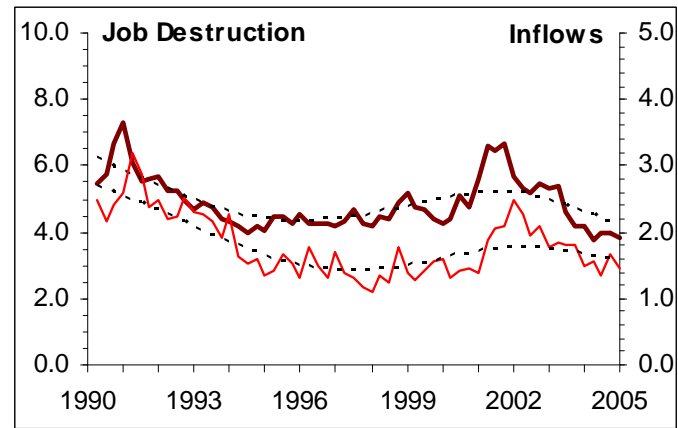

Transportation \& Utilities

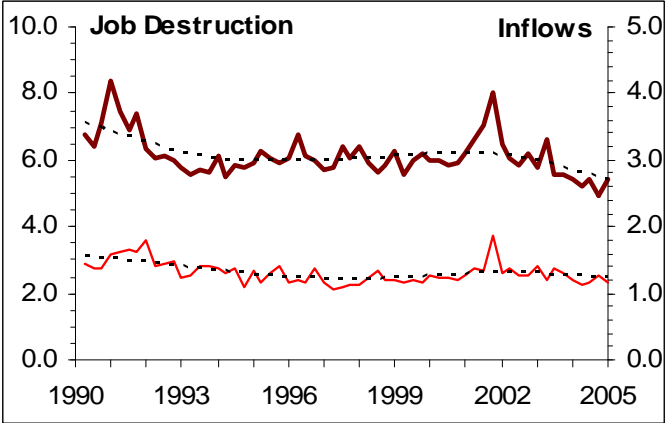

FIRE

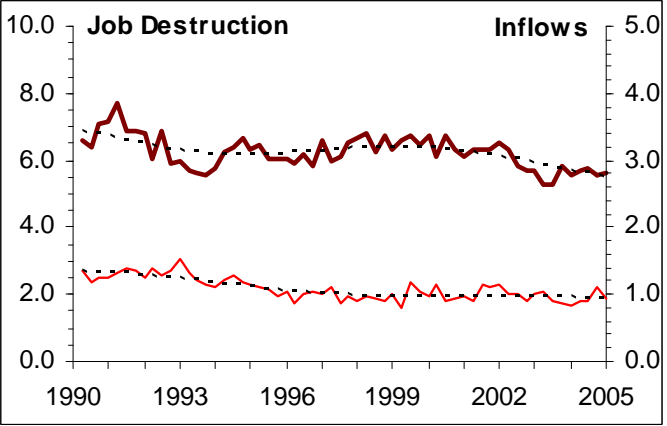

Construction

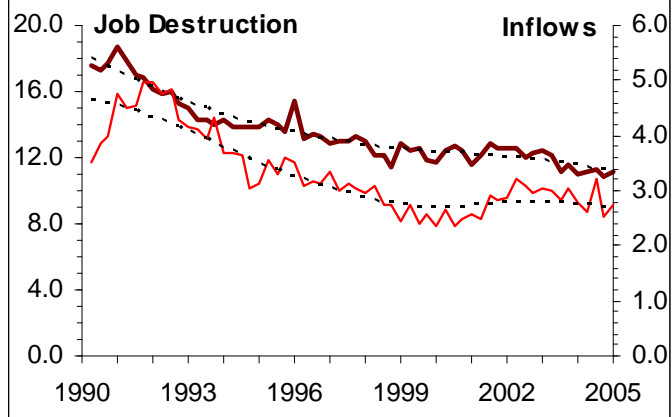

Nondurable Goods Manufacturing

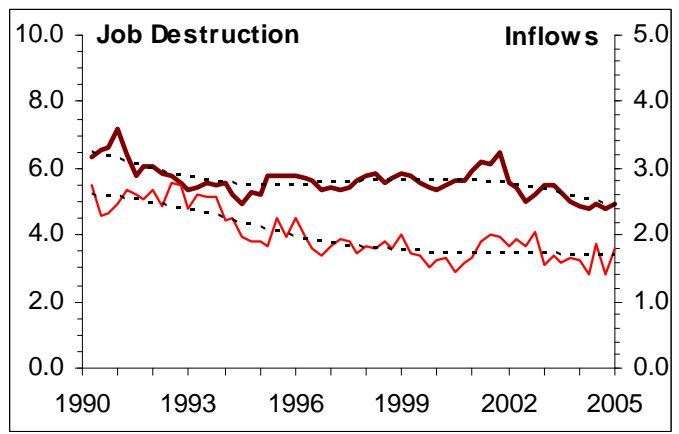

Wholesale \& Retail Trade

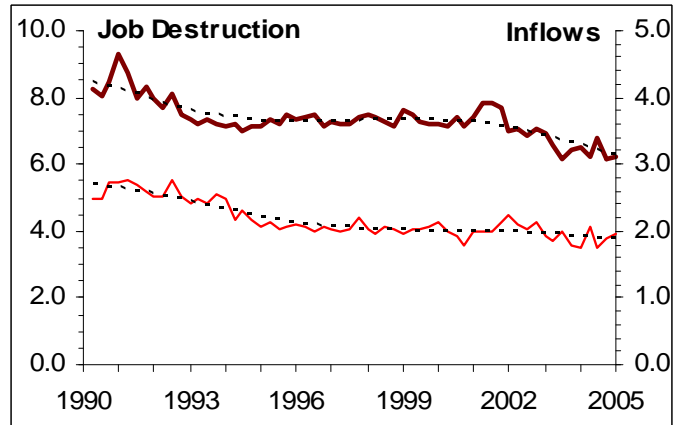

Services

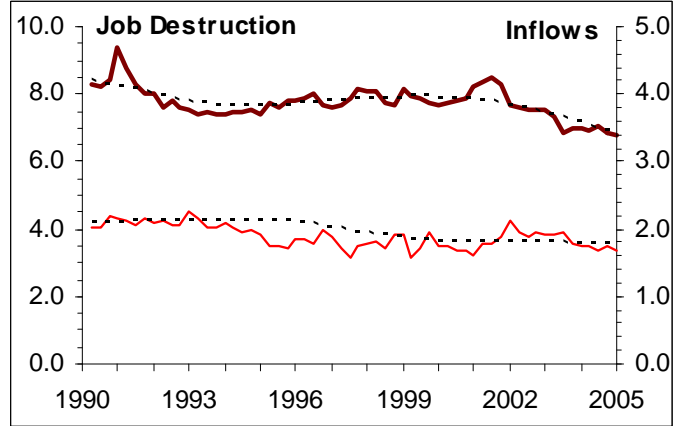

Notes: The figures show industry-level job destruction and unemployment inflow rates (percent of employment) and Hodrick-Prescott trends with smoothing parameter $\lambda=1600$. Job destruction rates are from Business Employment Dynamics and unemployment inflow rates are from the Current Population Survey. 
Figure 10. Job Destruction and Unemployment Inflow Rates by Industry, Annual

\section{Mining}

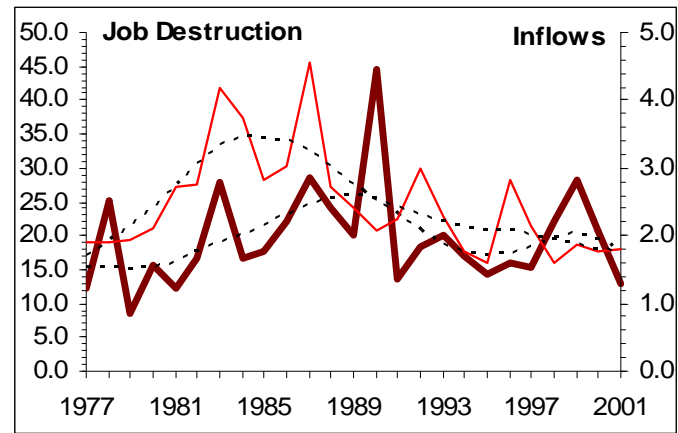

Durable Goods Manufacturing

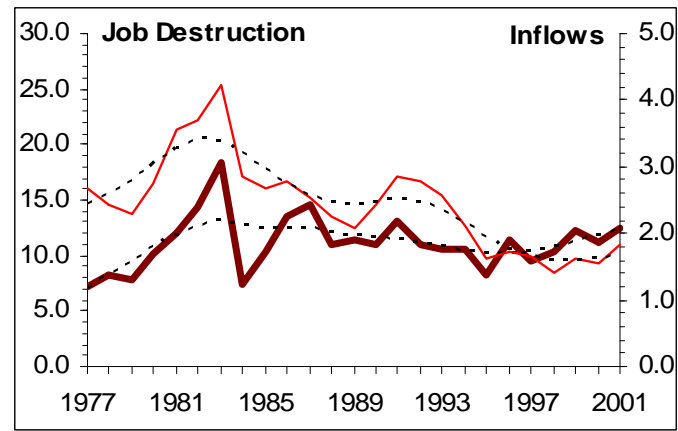

Transportation \& Utilities

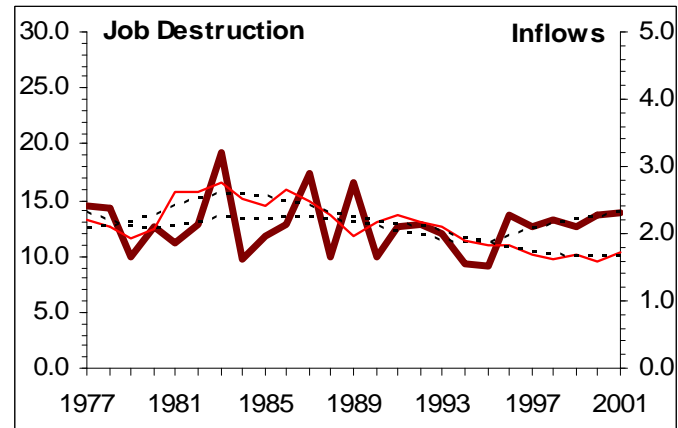

FIRE

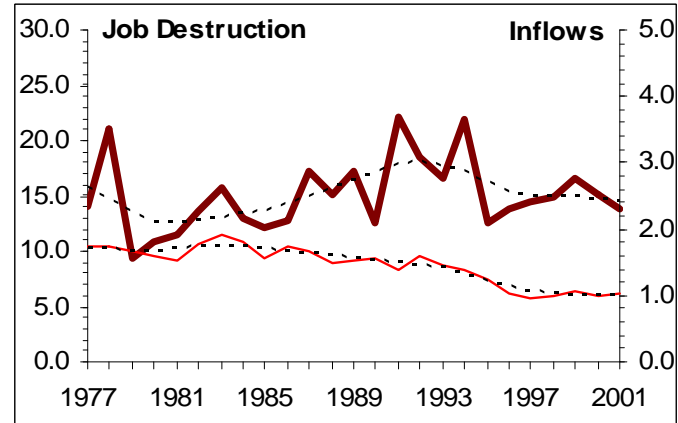

Construction

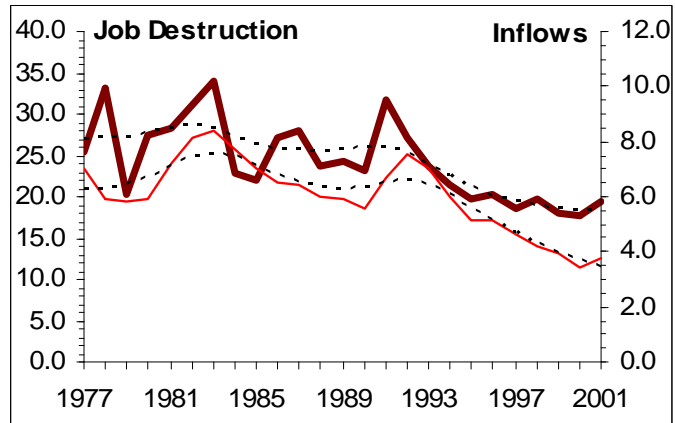

Nondurable Goods Manufacturing

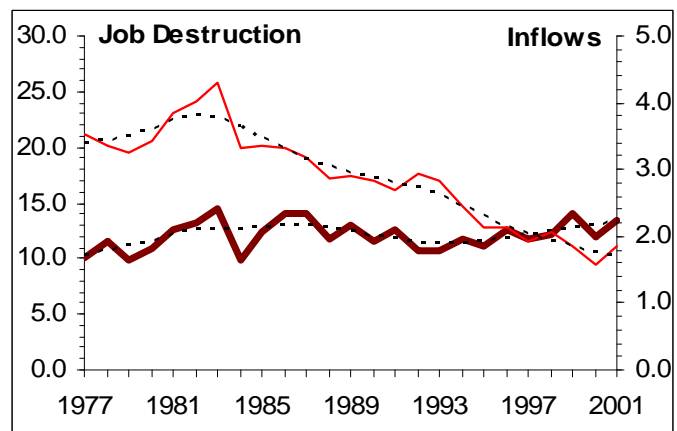

Wholesale \& Retail Trade

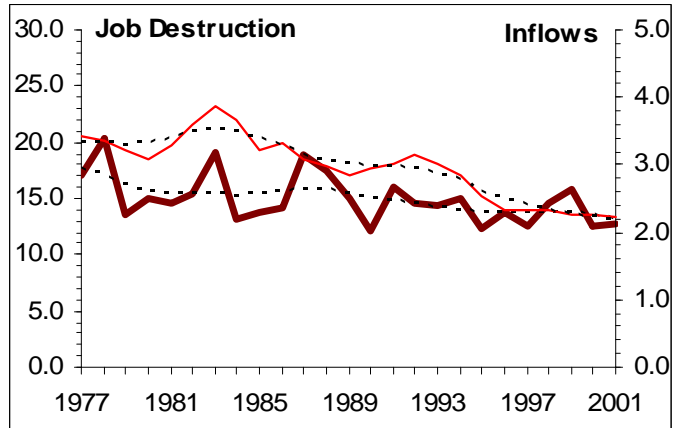

Services

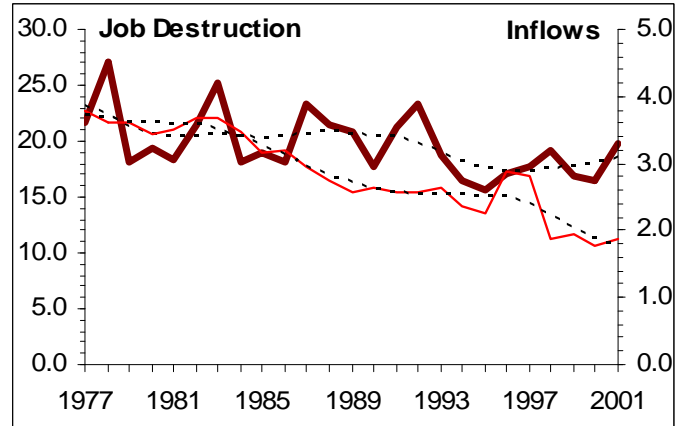

Notes: The figures show industry-level job destruction and unemployment inflow rates (percent of employment) and Hodrick-Prescott trends with smoothing parameter $\lambda=6.25$. Job destruction rates are from the Longitudinal Business Database and unemployment inflow rates are from the Current Population Survey. 
Figure 11. Quarterly Job Destruction and Unemployment Inflows by Industry, Three-Year Averages, Controlling for Time and Industry Fixed Effects

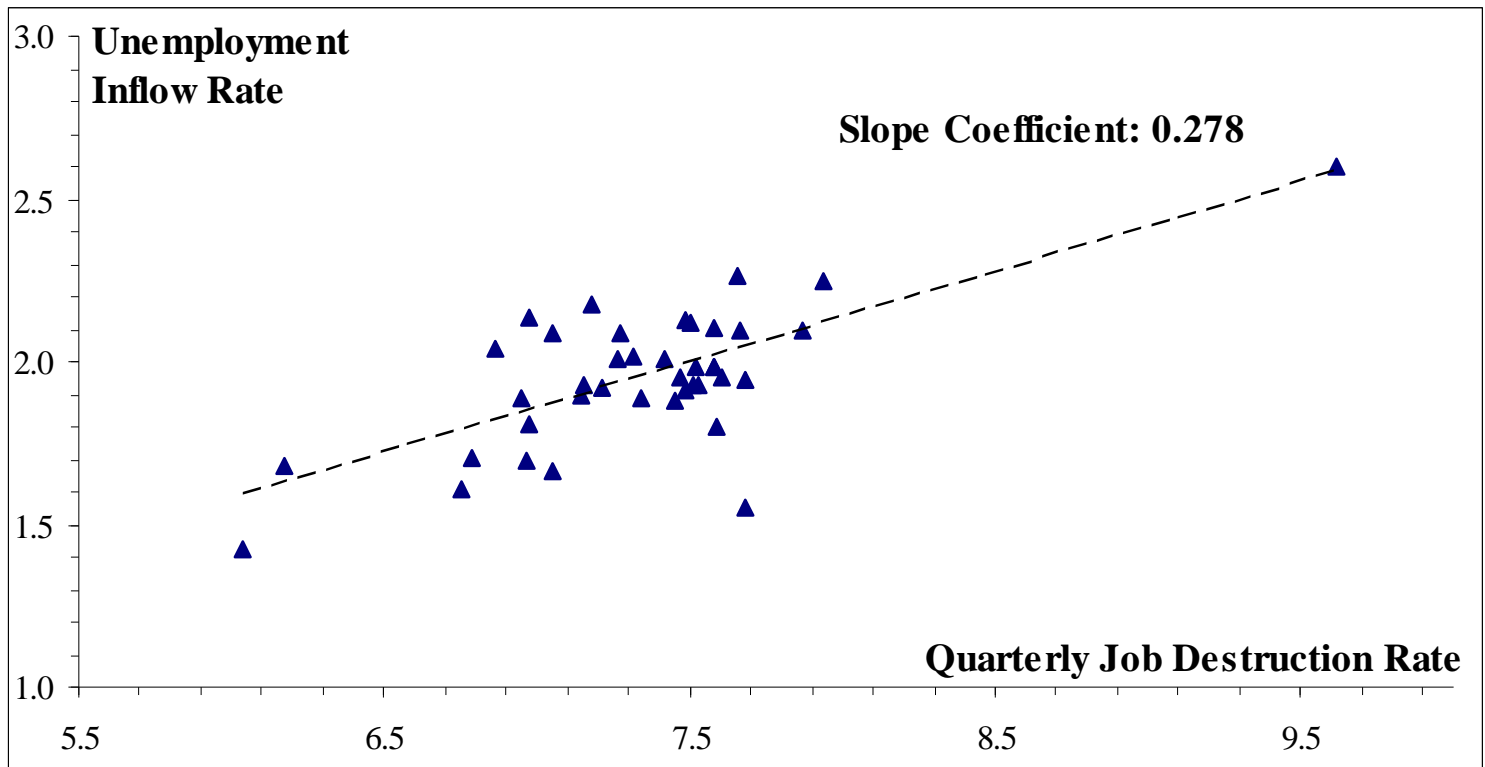

Note: Data are residuals in regressions of three-year average values of monthly unemployment inflow rates and quarterly job destruction rates on time and industry fixed effects. The overall means have been added back to the residuals. The dashed line shows the fitted least-squares relationship, which corresponds to column (4) in Table 3(a).

Figure 12. Annual Job Destruction and Unemployment Inflows by Industry, Three-Year Averages, Controlling for Time and Industry Fixed Effects

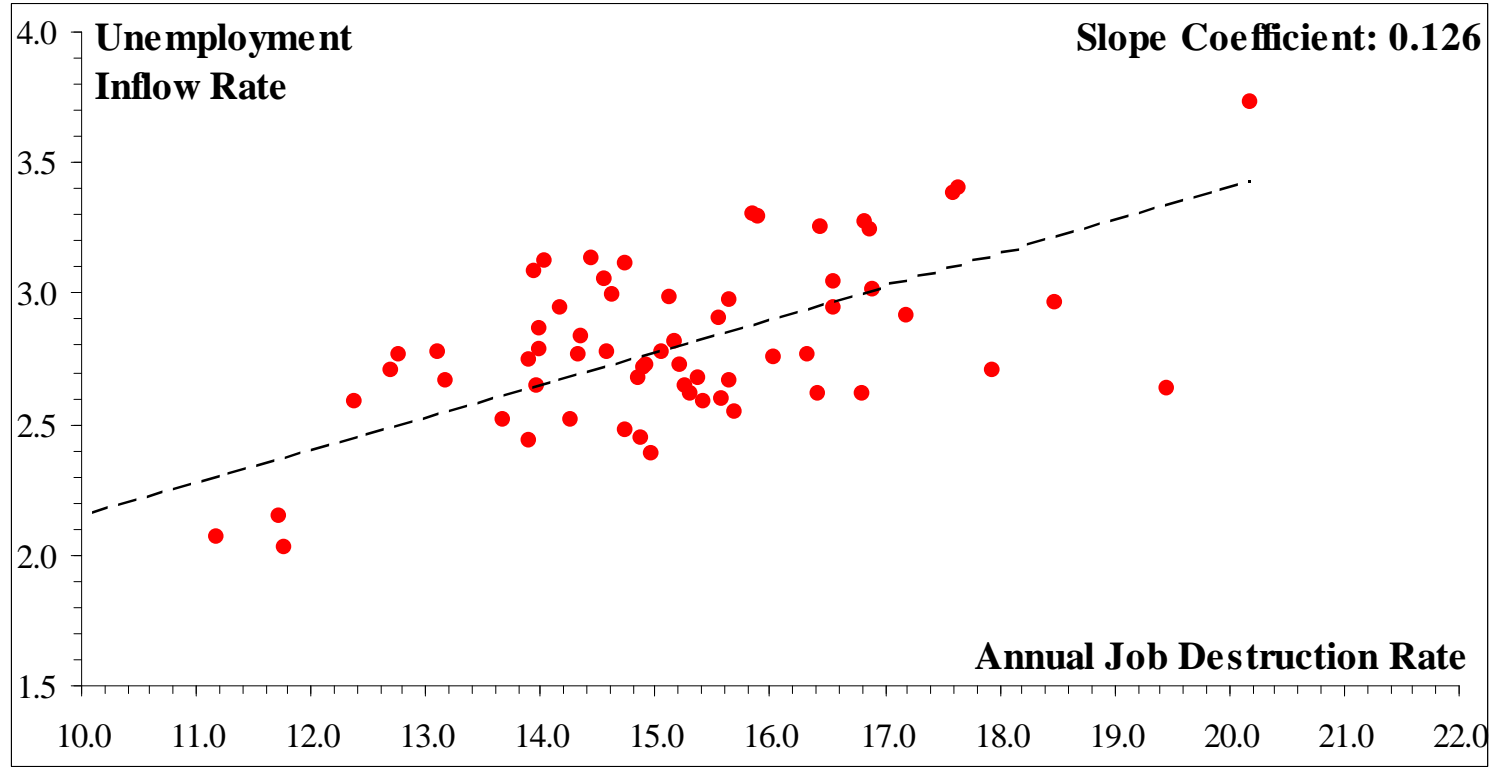

Note: Data are residuals in regressions of three-year average values of monthly unemployment inflow rates and annual job destruction rates on time and industry fixed effects. The overall means have been added back to the residuals. The dashed line shows the fitted least-squares relationship, which corresponds to column (6) in Table 3(b). 
Figure 13. Actual Unemployment Rate Compared to Steady State Value Implied by Contemporaneous Unemployment Inflow and Escape Rates

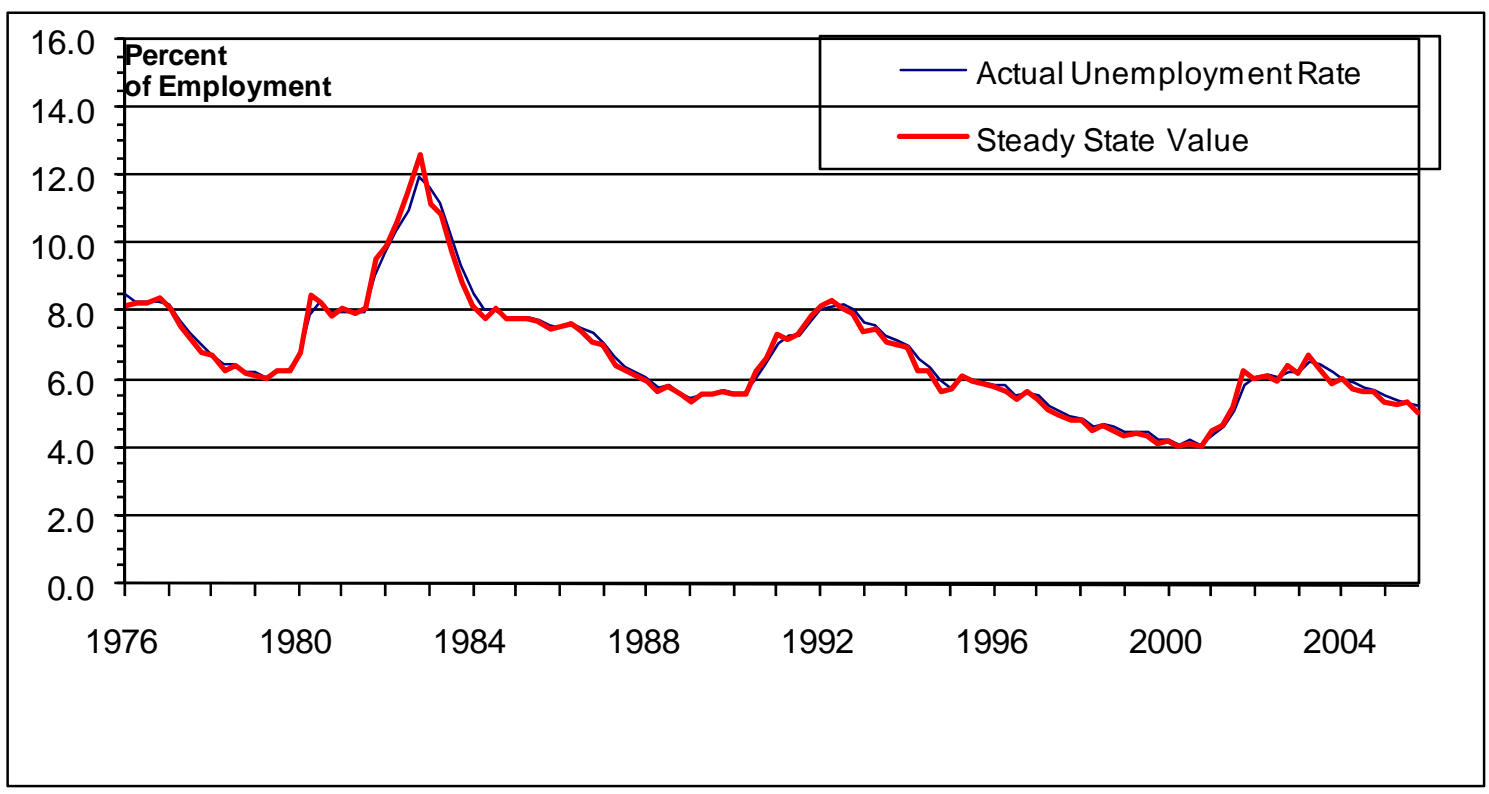

Note: Unemployment rate defined as the ratio of unemployment to employment. The steady state value of the unemployment rate calculated according to equation (6) in the text. All values in the figure are quarterly averages of monthly rates.

\section{Figure 14. Steady State Unemployment, Alternative Unemployment Inflow Rates}

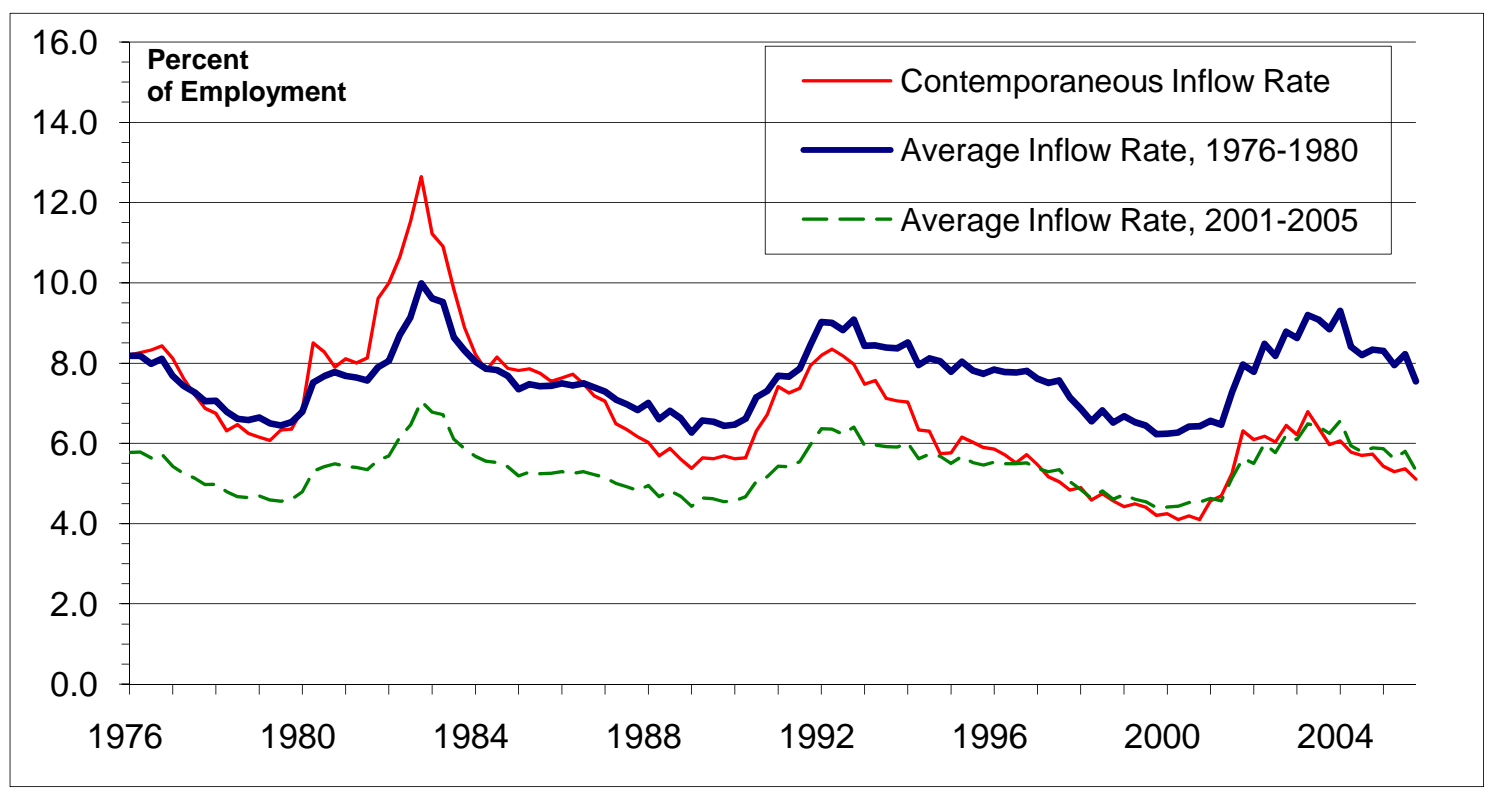

Note: The figure shows time series for the steady state unemployment rate computed from (6) using the contemporaneous unemployment escape rate and the indicated unemployment inflow rate. 
Table 1. Sample Means of BED and CPS Measures, 1990 to 2005

\begin{tabular}{|c|c|c|c|c|c|c|}
\hline & \multicolumn{4}{|c|}{ Quarterly Rates (BED) } & \multicolumn{2}{|c|}{ Monthly Rates (CPS) } \\
\hline & $\begin{array}{c}\text { Job } \\
\text { Destruction }\end{array}$ & $\begin{array}{l}\text { Job Destruction, } \\
\text { Continuers }\end{array}$ & $\begin{array}{c}\text { Job Destruction, } \\
\text { Exits }\end{array}$ & $\begin{array}{c}\text { Job } \\
\text { Reallocation }\end{array}$ & $\begin{array}{l}\text { Unemployment } \\
\text { Inflows }\end{array}$ & $\begin{array}{l}\text { Unemployment } \\
\text { Escape }\end{array}$ \\
\hline Mining & 7.1 & 5.5 & 1.6 & 13.8 & 1.9 & 36.6 \\
\hline Construction & 13.5 & 10.6 & 2.9 & 27.4 & 3.3 & 39.2 \\
\hline $\begin{array}{l}\text { Manufacturing, Nondurable } \\
\text { Goods }\end{array}$ & 5.6 & 4.6 & 1.0 & 10.8 & 2.0 & 33.5 \\
\hline $\begin{array}{l}\text { Manufacturing, Durable } \\
\text { Goods }\end{array}$ & 4.9 & 4.1 & 0.8 & 9.4 & 1.8 & 33.4 \\
\hline Transportation \& Utilities & 6.1 & 4.9 & 1.3 & 12.5 & 1.3 & 35.1 \\
\hline Retail \& Wholesale Trade & 7.3 & 5.9 & 1.4 & 14.8 & 2.2 & 38.2 \\
\hline FIRE & 6.2 & 4.5 & 1.7 & 12.7 & 1.1 & 33.3 \\
\hline Services & 7.7 & 6.0 & 1.7 & 16.1 & 1.9 & 38.9 \\
\hline All, Private Employment & 7.6 & 6.0 & 1.6 & 15.6 & 2.2 & 38.1 \\
\hline
\end{tabular}

Notes: Major industry groups for the integrated BED-CPS data set are defined on a NAICS basis. All BED job flow statistics are computed using establishmentlevel employment changes from the third month in the prior quarter to the third month in the current quarter. Job flows and unemployment inflows are expressed as a percent of employment, while escape rates are expressed as a percent of unemployment. 
Table 2. Sample Means of LBD and CPS Measures, 1977 to 2001

\begin{tabular}{|c|c|c|c|c|c|c|c|c|}
\hline & \multicolumn{6}{|c|}{ Annual Rates (LBD) } & \multicolumn{2}{|c|}{ Monthly Rates (CPS) } \\
\hline & $\begin{array}{c}\text { Job } \\
\text { Destruction }\end{array}$ & $\begin{array}{l}\text { Job Dest., } \\
\text { Continuers }\end{array}$ & $\begin{array}{l}\text { Job Dest., } \\
\text { Exits }\end{array}$ & $\begin{array}{c}\text { Job } \\
\text { Reallocation }\end{array}$ & $\begin{array}{c}\text { Firm } \\
\text { Volatility }\end{array}$ & $\begin{array}{c}\text { Firm } \\
\text { Dispersion }\end{array}$ & $\begin{array}{c}\text { Unemployment } \\
\text { Inflows }\end{array}$ & $\begin{array}{c}\text { Unemployment } \\
\text { Escape }\end{array}$ \\
\hline Mining & 19.6 & 13.4 & 6.2 & 36.2 & 51.4 & 64.1 & 2.5 & 37.0 \\
\hline Construction & 24.3 & 15.1 & 9.2 & 51.6 & 68.8 & 78.2 & 6.0 & 40.6 \\
\hline $\begin{array}{l}\text { Manufacturing, } \\
\text { Nondurable Goods }\end{array}$ & 12.1 & 7.7 & 4.4 & 24.2 & 34.1 & 48.9 & 2.9 & 39.3 \\
\hline $\begin{array}{l}\text { Manufacturing, } \\
\text { Durable Goods }\end{array}$ & 11.1 & 7.6 & 3.6 & 22.7 & 33.0 & 46.7 & 2.4 & 35.6 \\
\hline $\begin{array}{l}\text { Transportation \& } \\
\text { Utilities }\end{array}$ & 12.7 & 7.6 & 5.2 & 27.8 & 40.5 & 55.9 & 2.1 & 37.3 \\
\hline $\begin{array}{l}\text { Retail \& } \\
\text { Wholesale Trade }\end{array}$ & 15.0 & 8.6 & 6.3 & 32.2 & 46.4 & 61.9 & 3.0 & 44.7 \\
\hline FIRE & 15.1 & 8.2 & 6.9 & 32.0 & 46.8 & 61.9 & 1.5 & 38.8 \\
\hline Services & 19.7 & 11.0 & 8.7 & 44.3 & 51.3 & 66.4 & 2.9 & 43.5 \\
\hline $\begin{array}{l}\text { All, Private } \\
\text { Employment }\end{array}$ & 15.1 & 8.8 & 6.3 & 32.2 & 45.9 & 61.1 & 2.8 & 41.1 \\
\hline
\end{tabular}

Notes: Major industry groups for the integrated LBD-CPS data set are defined on n SIC basis. All LBD job flow statistics are computed using firm-level employment changes from the payroll period covering March 12 in the prior year to the payroll period covering Mach 12 in the current year. Job flows and unemployment inflows are expressed as a percent of employment, while escape rates are expressed as a percent of unemployment. 
Table 3. Unemployment Inflows and Empirical Indicators for Idiosyncratic Shock Intensity, Three-Year Averages of Industry-Level Values

Dependent Variable: Unemployment Inflows (Average of Monthly Rates)

(a) Using CPS and BED Data, 1990Q2 to 2005Q1

\begin{tabular}{|c|c|c|c|c|c|c|}
\hline $\begin{array}{c}\text { Independent } \\
\text { Variables }\end{array}$ & (1) & (2) & (3) & (4) & (5) & (6) \\
\hline$J D_{i t}$ & $\begin{array}{c}0.323 \\
(0.038)\end{array}$ & & & $\begin{array}{c}0.278 \\
(0.058)\end{array}$ & & \\
\hline$J D_{i t} \mid$ Cont & & $\begin{array}{c}0.269 \\
(0.227)\end{array}$ & & & $\begin{array}{c}0.264 \\
(0.115)\end{array}$ & \\
\hline$J D_{i t} \mid$ Exit & & $\begin{array}{c}0.483 \\
(0.568)\end{array}$ & & & $\begin{array}{c}0.327 \\
(0.318)\end{array}$ & \\
\hline$J R_{i t}$ & & & $\begin{array}{c}0.187 \\
(0.021)\end{array}$ & & & $\begin{array}{c}0.174 \\
(0.021)\end{array}$ \\
\hline $\begin{array}{l}\text { Industry } \\
\text { Effects }\end{array}$ & Yes & Yes & Yes & Yes & Yes & Yes \\
\hline $\begin{array}{l}\text { Time } \\
\text { Effects }\end{array}$ & No & No & No & Yes & Yes & Yes \\
\hline R-Squared & 0.915 & 0.916 & 0.912 & 0.956 & 0.956 & 0.959 \\
\hline $\begin{array}{l}\text { Within } \\
\text { R-Squared }\end{array}$ & 0.608 & 0.609 & 0.589 & 0.500 & 0.500 & 0.540 \\
\hline
\end{tabular}

(b) Using CPS and LBD Data, 1977 to 2001

\begin{tabular}{|c|c|c|c|c|c|c|c|c|c|c|}
\hline $\begin{array}{c}\text { Independent } \\
\text { Variables }\end{array}$ & (1) & (2) & (3) & (4) & (5) & (6) & (7) & (8) & (9) & (10) \\
\hline$J D_{i t}$ & $\begin{array}{c}0.163 \\
(0.059)\end{array}$ & & & & & $\begin{array}{c}0.126 \\
(0.036)\end{array}$ & & & & \\
\hline$J D_{i t} \mid$ Cont & & $\begin{array}{c}0.141 \\
(0.062)\end{array}$ & & & & & $\begin{array}{c}0.118 \\
(0.040)\end{array}$ & & & \\
\hline$J D_{i t} \mid$ Exit & & $\begin{array}{c}0.211 \\
(0.058)\end{array}$ & & & & & $\begin{array}{c}0.148 \\
(0.065)\end{array}$ & & & \\
\hline$J R_{i t}$ & & & $\begin{array}{c}0.108 \\
(0.027)\end{array}$ & & & & & $\begin{array}{c}0.063 \\
(0.024)\end{array}$ & & \\
\hline$\sigma_{i t}(\mathrm{Vol})$ & & & & $\begin{array}{c}0.093 \\
(0.018)\end{array}$ & & & & & $\begin{array}{c}0.034 \\
(0.027)\end{array}$ & \\
\hline$\sigma_{i t}(D i s p)$ & & & & & $\begin{array}{c}0.070 \\
(0.022)\end{array}$ & & & & & $\begin{array}{c}0.036 \\
(0.023)\end{array}$ \\
\hline $\begin{array}{l}\text { Industry } \\
\text { Effects }\end{array}$ & Yes & Yes & Yes & Yes & Yes & Yes & Yes & Yes & Yes & Yes \\
\hline $\begin{array}{l}\text { Time } \\
\text { Effects }\end{array}$ & No & No & No & No & No & Yes & Yes & Yes & Yes & Yes \\
\hline R-Squared & 0.851 & 0.854 & 0.846 & 0.868 & 0.838 & 0.964 & 0.964 & 0.953 & 0.944 & 0.947 \\
\hline $\begin{array}{l}\text { Within } \\
\text { R-squared }\end{array}$ & 0.309 & 0.321 & 0.288 & 0.388 & 0.252 & 0.413 & 0.418 & 0.236 & 0.101 & 0.138 \\
\hline
\end{tabular}


Note: The table reports slope coefficients and robust standard errors clustered on industries (in parentheses) for least-squares regressions of unemployment inflow rates on empirical indicators for the intensity of idiosyncratic labor demand shocks. All regressions are run on a panel of 3-year mean values for 8 major industries. The BED-CPS data in Panel (a) contain 40 observations, 5 per industry. The LBD-CPS data in Panel (b) contain 64 observations, 8 per industry. The "Within R-squared" value shows the coefficient of determination for the variation that remains after sweeping out the indicated fixed effects. 
Table 4: Unemployment Escape Rates and Empirical Indicators for Idiosyncratic Shock Intensity, Three-Year Averages of Industry-Level Values

\section{Dependent Variable: Unemployment Escape Rate (Average of Monthly Values)}

(a) Using CPS and BED Data, 1990Q2 to 2005Q1

\begin{tabular}{|c|c|c|c|c|c|c|}
\hline $\begin{array}{c}\text { Independent } \\
\text { Variables }\end{array}$ & (1) & (2) & (3) & (4) & (5) & (6) \\
\hline$J D_{i t}$ & $\begin{array}{c}0.498 \\
(1.254)\end{array}$ & & & $\begin{array}{c}-1.355 \\
(0.361)\end{array}$ & & \\
\hline$J D_{i t} \mid$ Cont & & $\begin{array}{c}-1.835 \\
(4.082)\end{array}$ & & & $\begin{array}{c}-1.133 \\
(0.763)\end{array}$ & \\
\hline$J D_{i t} \mid$ Exit & & $\begin{array}{c}7.392 \\
(11.398)\end{array}$ & & & $\begin{array}{l}-2.132 \\
(1.575)\end{array}$ & \\
\hline$J R_{i t}$ & & & $\begin{array}{c}0.340 \\
(0.794)\end{array}$ & & & $\begin{array}{l}-0.753 \\
(0.103)\end{array}$ \\
\hline $\begin{array}{l}\text { Industry } \\
\text { Effects }\end{array}$ & Yes & Yes & Yes & Yes & Yes & Yes \\
\hline $\begin{array}{l}\text { Time } \\
\text { Effects }\end{array}$ & No & No & No & Yes & Yes & Yes \\
\hline R-Squared & 0.281 & 0.298 & 0.283 & 0.946 & 0.947 & 0.943 \\
\hline $\begin{array}{l}\text { Within } \\
\text { R-Squared }\end{array}$ & 0.010 & 0.034 & 0.013 & 0.314 & 0.315 & 0.267 \\
\hline
\end{tabular}

(b) Using CPS and LBD Data, 1977 to 2001

\begin{tabular}{|c|c|c|c|c|c|c|c|c|c|c|}
\hline $\begin{array}{c}\text { Independent } \\
\text { Variables }\end{array}$ & (1) & (2) & (3) & (4) & (5) & (6) & (7) & (8) & (9) & (10) \\
\hline$J D_{i t}$ & $\begin{array}{l}-0.344 \\
(0.239)\end{array}$ & & & & & $\begin{array}{l}-0.507 \\
(0.128)\end{array}$ & & & & \\
\hline$J D_{i t} \mid$ Cont & & $\begin{array}{c}-0.732 \\
(0.358)\end{array}$ & & & & & $\begin{array}{c}-0.619 \\
(0.143)\end{array}$ & & & \\
\hline$J D_{i t} \mid$ Exit & & $\begin{array}{c}0.533 \\
(0.517)\end{array}$ & & & & & $\begin{array}{c}-0.174 \\
(0.222)\end{array}$ & & & \\
\hline$J R_{i t}$ & & & $\begin{array}{l}-0.101 \\
(0.196)\end{array}$ & & & & & $\begin{array}{l}-0.140 \\
(0.174)\end{array}$ & & \\
\hline$\sigma_{i t}(\mathrm{Vol})$ & & & & $\begin{array}{l}-0.283 \\
(0.056)\end{array}$ & & & & & $\begin{array}{l}-0.039 \\
(0.231)\end{array}$ & \\
\hline$\sigma_{i t}(D i s p)$ & & & & & $\begin{array}{l}-0.035 \\
(0.122)\end{array}$ & & & & & $\begin{array}{l}-0.058 \\
(0.151)\end{array}$ \\
\hline $\begin{array}{l}\text { Industry } \\
\text { Effects }\end{array}$ & Yes & Yes & Yes & Yes & Yes & Yes & Yes & Yes & Yes & Yes \\
\hline $\begin{array}{l}\text { Time } \\
\text { Effects }\end{array}$ & No & No & No & No & No & Yes & Yes & Yes & Yes & Yes \\
\hline R-Squared & 0.339 & 0.400 & 0.321 & 0.373 & 0.318 & 0.839 & 0.843 & 0.814 & 0.809 & 0.811 \\
\hline $\begin{array}{l}\text { Within } \\
\text { R-squared }\end{array}$ & 0.032 & 0.121 & 0.006 & 0.082 & 0.001 & 0.157 & 0.180 & 0.027 & 0.003 & 0.009 \\
\hline
\end{tabular}


Note: The table reports slope coefficients and robust standard errors clustered on industries (in parentheses) for least-squares regressions of unemployment escape rates on empirical indicators for the intensity of idiosyncratic labor demand shocks. All regressions are run on a panel of 3-year mean values for 8 major industries. The BED-CPS data in Panel (a) contain 40 observations, 5 per industry. The LBD-CPS data in Panel (b) contain 64 observations, 8 per industry. The "Within R-squared" value shows the coefficient of determination for the variation that remains after sweeping out the indicated fixed effects. 